NBER WORKING PAPER SERIES

COGNITION AND ECONOMIC OUTCOMES IN THE HEALTH AND RETIREMENT SURVEY

John J. McArdle

James P. Smith

Robert Willis

Working Paper 15266

http://www.nber.org/papers/w15266

\author{
NATIONAL BUREAU OF ECONOMIC RESEARCH \\ 1050 Massachusetts Avenue \\ Cambridge, MA 02138 \\ August 2009
}

We would like to thank Iva MacLennan and David Rumpel for excellent programming assistance and Finis Welch and Ian Walker for their insightful comments on earlier drafts. This research was supported by grants (AG025529 and AG 008291) from the National Institute of Aging to the Rand Corporation, to the University of Southern California (AG\#07137) and to the University of Michigan (AG026571). This paper was presented at the NBER conference on Economics of Aging in Carefree Arizona. The views expressed herein are those of the author(s) and do not necessarily reflect the views of the National Bureau of Economic Research.

NBER working papers are circulated for discussion and comment purposes. They have not been peerreviewed or been subject to the review by the NBER Board of Directors that accompanies official NBER publications.

(C) 2009 by John J. McArdle, James P. Smith, and Robert Willis. All rights reserved. Short sections of text, not to exceed two paragraphs, may be quoted without explicit permission provided that full credit, including $\odot$ notice, is given to the source. 
Cognition and Economic Outcomes in the Health and Retirement Survey

John J. McArdle, James P. Smith, and Robert Willis

NBER Working Paper No. 15266

August 2009

JEL No. J0

\begin{abstract}
$\underline{\text { ABSTRACT }}$
Dimensions of cognitive skills are potentially important but often neglected determinants of the central economic outcomes that shape overall well-being over the life course. There exists enormous variation among households in their rates of wealth accumulation, their holdings of financial assets, and the relative risk in their chosen asset portfolios that have proven difficult to explain by conventional demographic factors, the amount of bequests they receive or anticipating giving, and the level of economic resources of the household. These may be cognitively demanding decisions at any age but especially so at older ages. This research examines the association of cognitive skills with wealth, wealth growth, and wealth composition for people in their pre and post-retirement years.
\end{abstract}

John J. McArdle

USC College of Letters, Arts and Sciences 3551 Trousdale Pkwy.

Los Angeles, CA 90089-4012

mcardlej@verizon.net

James P. Smith

Labor and Pop Studies Program

The RAND Corporation

1776 Main Street

Santa Monica, CA 90406

smith@rand.org
Robert Willis

Health and Retirement Study 426 Thompson St., 3048 ISR

Ann Arbor, MI 48104

rjwillis@umich.edu 
Dimensions of cognitive skills are potentially important but often neglected determinants of the central economic outcomes that shape overall well-being over the life course. There exists enormous variation among households in their rates of wealth accumulation, their holdings of financial assets, and the relative risk in their chosen asset portfolios that have proven difficult to explain by conventional demographic factors, the amount of bequests they receive or anticipating giving (Smith, 1999), and the level of economic resources of the household (Smith, 1995). The premium on cognitive skills in economic decision making may also be increasing as individuals are increasingly asked to take greater control of or to adjust prior decisions relating to their household wealth, their pensions, and their health care. These may be cognitively demanding decisions at any age but especially so at older ages.

This research will examine the association of cognitive skills with wealth, wealth growth, and wealth composition for people in their pre and post-retirement years. Our analysis will rely on selective waves of the Health and Retirement Survey (HRS), a nationally representative panel survey of Americans who are at least fifty years. This analysis will be supplemented by a cognitive economics survey (Cog Econ) that measured several dimensions of cognition in more depth.

HRS is well-known for its high quality measurement of many key SES outcomes; including income and wealth (see Juster and Smith, 1997 and Juster, Smith, and Stafford, 1999). In addition, HRS includes in some waves several salient dimensions of cognitive skills. These cognition constructs start with immediate and delayed memory recall and the TICS battery as these have been established psychometrically to capture cognitive constructs of episodic memory and intact mental status (see McArdle, Fisher \& Kadlec, 2007). Another key aspect of cognition included in recent HRS waves is numeracy, a simple summary measure of respondents' 
numerical ability. We also present data on two additional measures of numerical reasoning and retrieval fluency, both recently introduced into the HRS as experimental modules, to examine if these dimensions of cognition are associated with significant improvements in the ability of cognition to predict economic outcomes.

The paper is organized into six sections. The next section presents the main conceptual components of cognition that may potentially influence economic outcomes. The following section describes the main data that we will use and the cognition variables available in the HRS. The third section highlights results that are obtained relating individual attributes, including their cognitive ability, to their total wealth, total financial wealth, and the fraction of wealth held in stock. The next section contains complementary results obtained from the cognitive economics survey (CogEcon), which has a more expansive list of cognitive variables. Section five widens our focus by summarizing results obtained for joint spousal cognitive variables on the financial outcomes of the household. This section includes models of who within the family becomes the main financial decision-maker. The final section highlights our main conclusions.

\section{Cognition and Economics}

The mechanisms responsible for cognitive development over the life course that are related to economic outcomes may be the long term result of many individual and group factors. It is established that children exposed to very serious environmental deprivation show markedly reduced cognitive abilities (Rutter, 1985), but detectable effects of normal-range environments on cognitive ability are typically smaller. This is not surprising, given the large number of environmental risk factors and the small effect expected for any particular factor, and that the genetic contributions vary as well (Harden et al, 2007). Specific factors associated with lower cognitive performance include low socioeconomic status, birth complications, poor early 
nutrition, family conflict, and many others (Conger et al., 1994; Ramey et al. 2000).

In a classic analysis of data from the Berkeley Studies, Elder (1974) found that effects of economic deprivation on adult functioning varied with gender and birth cohort. For males in the older cohort (OGS, born 1920-22), being reared in a family with low SES during the Great Depression was associated with higher resilience in adulthood compared to males reared in more favorable circumstances. In contrast, for boys in the younger cohorts (BGS and GS, born 192830) being reared in economic adversity was associated with lower psychological functioning in adulthood. These processes applied equally well to behavior of mothers and fathers, as well as sons and daughters. Lee et al. (2003) investigated the relation of educational attainment, husband's education, household income, and childhood socioeconomic status to cognitive function and decline among community-dwelling women aged 70-79 years. Among welleducated women, educational attainment predicted cognitive function and decline, although other measures of socioeconomic status had little relation.

Whatever the origin of adult cognitive skills, financial matters are often not straightforward for most individuals and may depend in part on their ability to invoke several dimensions of cognitive skills. One needs to be interested in economic problems and feel comfortable in understanding the choices that are available amidst a wide array of options and feel confident about the computations involved in contrasting alterative rates of return of different assets often calculated over different time dimensions (Banks and Oldfield, 2007). This may involve aspects of (a) retrieving relevant prior financial information from memory, (b) using one's accumulated knowledge and skills (Crystallized intelligence (Gc)), and (c) the ability to draw inferences about what is the best solution to a novel problem (Fluid intelligence (Gf)); for details, see Cattell, 1987; Horn \& McArdle, 2007; McArdle \& Woodcock, 1998). 
A useful shorthand division of the principal dimensions of intelligence is to separate them into fluid intelligence (Gf) and crystallized intelligence (Gc). Fluid intelligence is the thinking part- memory, abstract reasoning, and executive function. In contrast, crystallized intelligence is the knowing part- the main accumulation of influence from education and lifetime experience (for more details, see McArdle, et al., 2002).

A parallel has been drawn between the psychological theory of fluid and crystallized intelligence and economic theories of investment in human capital. In the formulation of Willis (2007), based on the Ben-Porath human capital production function, fluid intelligence can be thought of as the ability parameter and crystallized intelligence as the accumulated stock of human capital. To be more concrete, the conceptual relationship between these aspects of cognition and human capital knowledge might be summarized as

$$
\text { (1) } Q_{t}=B_{0}\left(s_{t} K_{t}\right)^{B}{ }_{1} D_{t}{ }^{B}{ }_{2}
$$

In this model a production function relates the amount of learning or increments in human capital $\left(Q_{t}\right)$ to ability $\left(B_{0}\right)$, investments from existing stock of human capital $\left(K_{t}\right)$, and purchased market inputs $\left(D_{t}\right)$. Given its emphasis on ability to think and execute, fluid intelligence (Gf) most closely corresponds to the ability parameter $B_{0 .}$, In this production function crystallized intelligence $(\mathrm{Gc})$ role as a surrogate for accumulated knowledge is a close parallel to the existing stock of human capital or knowledge $\left(K_{t}\right)$. If we think of the output in equation (1) as increments in knowledge about financial matters, elements of cognition that mimic Gf and Gc will both affect this accumulation and affect financial outcomes. Of course, most everyday cognitive tasks have elements of both fluid and crystallized intelligence so there is not yet an established tight connection between cognitive measures and underlying parameters of the production process. 
In an insightful application, Delevande et al. (2008) consider an individual's knowledge of finance to be a component of human capital—or crystallized intelligence - that allows people to achieve a higher expected return on their assets, holding risk constant. They assume that an individual produces additional financial knowledge by combining his or her fluid intelligence or ability, crystallized intelligence and effort according to a human capital production function (Ben Porath, 1967; Cunha and Heckman, 2007). The motivation to acquire financial knowledge depends on an important scale economy in this investment process. While increased knowledge raises the feasible expected return per dollar, the total value of the investment depends on the number of dollars to which the improved return is applied.

Thus, other things equal, the value of acquiring financial knowledge is higher for persons who desire higher levels of retirement wealth because of a higher lifetime income, a lower rate of time preference or lower defined benefit pension wealth. Similarly, investment will be greater among persons who have lower costs or greater efficiency in acquiring additional knowledge because of greater fluid intelligence or because they have more financial knowledge obtained in their formal education or on-the-job.

Moreover, these issues may become increasingly salient as the population ages because many aspects of these basic cognitive skills are known to begin to deteriorate from different levels and at varying rates for individuals starting in middle age and often at even earlier ages. Figure 1 plots a simple summary of these age patterns separating out life cycle paths of over intelligence, as well as its fluid and crystallized intelligence components. As in other forms of human capital, crystallized intelligence is believed by cognitive psychologists to grow rapidly with age but at a decreasing rate plateauing somewhere in the age fifty age range. In contrast, 
elements of fluid intelligence are believed to peak relatively early in life (during adolescence) and then steadily decline with age thereafter.

Problems associated with declines in fluid intelligence with age may be compounded if older individuals are asked to take more personal control of their accounts and the financial decisions about their wealth holdings and its future trajectory (Hershey et al., 2007). It is possible that the recent financial collapse may place even greater demands on the ability of individuals to make good financial decisions about their wealth holdings in order to maintain income security during their retirement years. For many of these individuals there was little reason to acquire financial knowledge beforehand and they may now be left in a situation of relatively low levels of Gc coupled with rapidly declining levels of Gf.

\section{Data and Measures of Cognition in the Health and Retirement Survey}

This research will rely on a sub-set of surveys from the Health and Retirement Study (HRS), a nationally representative longitudinal survey of the population of the United States who are over fifty years old. The overall objective of the HRS is to monitor economic transitions in work, income, and wealth, as well as changes in many dimensions of health status among those over 50 years old. The current version of HRS is representative of all birth cohorts born in 1947 or earlier. Follow-ups of all surveys have taken place at approximately two-year intervals.

In HRS, questions were included in each core interview on demographics, income and wealth, family structure, health, and employment. An important advantage of these surveys is that they all contain high-quality wealth modules. In HRS, a very comprehensive and detailed set of questions was asked to measure household wealth. In addition to housing equity, assets were separated into the following eleven categories; other real estate; vehicles; business equity; IRA 
or Keogh; stocks or mutual funds; checking savings or money market funds; CD's, government savings bonds or treasury bills; other bonds; other assets; and other debt.

The subsets of HRS that we used are dictated by the types and availability of cognition measures in HRS (see Herzog \& Wallace, 1997; Herzog \& Rodgers, 1999; and Ofstedal et al. 2005). HRS cognition variables were intended to measure episodic memory, intactness of mental status, numerical reasoning, broad numeracy, and vocabulary. More recent work indicates that measures of cognitive speed can be obtained directly from the HRS, but these measures are relatively new and not yet available for this research.

We rely on two memory measures- immediate and delayed word recall available in HRS in every wave in the same form since 1995. Respondents are read a list of ten simple nouns and are then asked to immediately repeat as many of these words as they can in any order. After a five minute measurement of self-rated depression, they are then asked to recall as many of the original words as possible. ${ }^{1}$ Following the analysis of McArdle et al. (2007), we form an episodic memory measure as the average of immediate and delayed recalled results. Episodic memory may be a necessary component of reasoning (both fluid and crystallized intelligence).

Our second cognitive measure is the mental status questions of the Telephone Interview of Cognitive Status (TICS) battery established to capture intactness or mental status of individuals. TICS questions consist of the following items-serial 7 subtraction from 100 (up to five times), backwards counting (from 20 to 1), naming today's date (month, day, year), and naming the President and Vice-President of the United States. Answers to these questions are aggregated into a single mental status score that ranges from 0 to 10 . The same form of mental status scores have been available since AHEAD 95 and HRS 96 (Herzog \& Rodgers, 1999)

\footnotetext{
${ }^{1}$ In HRS 92 and 94, the original set consisted of twenty words. The same word list is not repeated in the next three subsequent rounds and husbands and wives were given a different list (see Ofstedal et al. 2005).
} 
The third cognition measure available is a number series test adapted from the Woodcock-Johnson (WJ-R) battery of tests for fluid reasoning (McArdle et al, 2007). This test was administered in a 2004 experimental module to a random sample of over 1200 respondents. This represented an attempt to achieve test scores from a subset of items from the number series test of WJ III using an adaptive testing methodology. Each respondent was asked no more than six items where the subsequent sequence of items at each point was determined by correctness of each answer. This test was administered again in a 2006 experimental module where roughly half of respondents who were tested in 2004 were tested again. Fifty percent of those given the test in the 2006 experimental module had not been tested previously. For each respondent, a score was created on the $\mathrm{W}$-scale (logit metric) where higher scores indicate better performance. Because this numerical reasoning test has not yet been placed in the HRS core, sample size is smaller and statistical power may be fairly low. To mitigate these problems, we maximized number of observations with a score by taking an available score from either the 2004 or 2006 experimental module if available. If respondents were tested twice, scores were averaged.

The forth measure deals with a WJ form of retrieval fluency, which was administered in an experimental module in HRS 2006. Respondents were given a category and asked to mention as many items as they could within a forty-five second time frame (shorter than the typical WJ format). The number of correct and incorrect answers was counted by the interviewer.

Starting with HRS 2002 and then asked in alternative waves for repeat interviews, three questions were added to the core interview to measure numeracy (respondents' numerical ability). These questions involve the computation of three mathematical computations and one is 
scored as either correct or incorrect on each of them. ${ }^{2}$ Four scores are possible running from zero to three depending on the number of correct answers.

Thus there are five different measures of cognition available in the HRS that we use in this analysis. While the episodic memory, mental status, and numeracy are available in multiple core waves in the same form, the other two measures are in an experimental module in a specific wave (number series and retrieval fluency). This form of availability determines the types of analysis that are possible with the full cognition measures.

A very simple schematic of the translation of these HRS cognition measures into the Gf and Gc components of intelligence is provided below. Episodic memory is a very general measure of an important aspect of fluid intelligence since access to memory is basic to any type of cognitive ability. Most of the HRS variation in this measure is picking out the low end- people with bad memory. Similarly, fluid reasoning, as captured by the number series, is perhaps our best measure of Gf for numerical ability skills most relevant for financial decision-making. Numeracy, the actual ability to perform numerical skills mostly learned in schools, represents our preferred measure of Gc for numbers. Retrieval fluency is possibly another proxy for Gc since it measures our retrieval of elements of accumulated knowledge although in this application it captures the retrieval of verbal knowledge (eg. the number of animals one can name in forty-five seconds) and not financial knowledge. We will deal with the ability to retrieve financial knowledge, a broader measure of math achievement, and general intelligence when we discuss the cognitive economics survey (CogEcon) survey below. Finally, the TICS score contains

\footnotetext{
${ }^{2}$ Another cognition measure is only available for the original cohort of HRS (those 51-61 years old in 1992) and was a one time measure. In HRS 92, a modified version of the Similarities subscale of the Wechsler Adult Intelligence Scale revised (WAIS-R). This was used to access higher level abstract reasoning by comparing a list of seven pairs of words and then describing how they were alike.
} 
elements of both Gf and Gc- cognitive skills needed for everything but specific to nothing. The types of questions asked are not specific to the financial domains of life

\section{Types of Cognition Measures Available in the Expanded HRS}

- Episodic Memory short term memory

- Telephone Interview of Intact Cognitive Status (TICS) - Gf and Gc - needed for everything but specific to nothing

- Number Series- Fluid Reasoning close to $G f$ for numerical ability

- Retrieval Fluency - Gc - ability to retrieve long term storage

- $\quad$ Numeracy $-G c$ for numbers or quantitative ability $-G q$

\section{$\underline{\text { Additional Measures in CogEcon }}$}

- Calculation- Gc- math achievement or general quantitative ability $G q$

- Matrix Reasoning- $G \boldsymbol{f}$ - non verbal reasoning and general intelligence

- Financial Literacy-Gc - knowledge of financial matters especially at the high end

The cognitive measures listed above are intended to indicate different aspects of the adult cognitive profile (see McArdle et al., 2002). Prior research has suggested strong normative age declines in most of these cognitive functions, but a hierarchy of cognitive strengths and weakness of any individual are indicated in many aspects of adult daily functioning. At a most basic level, the need for an intact neuro-cognitive system is thought to be necessary to deal with everyday issues in communication and learning in the simple judgments needed for survival (e.g., gathering food and water). At another step up in everyday complexity, the ability to remember to complete tasks, to be able to react to simple stimuli, and the ability to deal with simple numerical problems, are important skills in the consideration in successfully dealing with everyday challenges (see Farias et al, 2008) Higher order aspects of cognitive skills, such as having expertise in a specific area (i.e., Crystallized Intelligence), or in reasoning in novel 
situations (i.e., Fluid Intelligence), will be necessary fundaments in the ability to deal with more complex economic challenges (Hershey et al, 2007; McArdle et al, 2007).

As pointed out by Banks and Oldfield (2007), there are several credible reasons why numeracy, a score representing knowledge about numerical problems, may be related to financial outcomes. More numerate individuals may be more adept at complex decision-making including those involved in financial decisions (Peters et al. 2006). More numerate individuals also appear to be more patient and thus are more likely to have saved and invested in the past (Parker and Fischhoff, 2005) and perhaps less risk averse (Benjamin et al, 2006). ${ }^{3}$

The use of more abstract reasoning with numbers, as in the simple number series puzzles, is intended to represent a different form of cognition (i.e., fluid intelligence), and it is not clear how these abilities are useful in the accumulation of wealth). Examining results from a 25 -item test of financial knowledge on the Cognitive Economics Survey, Delevande, Willis and Rohwedder (2008) find that the number series score has a strong and significant effect on the test score as does educational attainment and number of economics courses the respondent has had. ${ }^{4}$ In addition, they find that women, especially older women, have considerably lower test scores than men, probably reflecting a household division of labor about household financial decisions that was especially sharp in earlier cohorts. These ideas about the independent impact of different forms of cognition are directly examined in this research.

\section{Individual level Analysis in the HRS}

In this section, we report our main empirical results describing the relation of these dimensions of cognition to wealth accumulation among middle aged and older adults. Table 1

\footnotetext{
${ }^{3}$ Reverse causality is possible where greater involvement in complex financial decisions improves numerical ability.

${ }^{4}$ The Cognitive Economics Survey, designed by a team of economists led by Willis, was administered during 2008 to a national sample of 1,222 persons, age 51 and older and their spouses regardless of age who are participants in the National Change and Growth Survey, a cognition survey designed by McArdle and colleagues (2002).
} 
lists means, medians, and standard deviations of variables that enter into the statistical analysis. Mean household wealth in this sample is about five hundred thousand dollars, but wealth has its well-known features of high variability and skewness as the median is just under two hundred thousand. Similarly, total financial wealth is around $\$ 313,000$ and is even more highly skewed as the median financial household wealth is only $\$ 56,000$. On average, nine percent of all financial wealth is held in stock. Mean household income is about sixty-two thousand dollars, but income is also very unequal across these individuals but not as much as wealth is.

Two-thirds of these individuals live as couples, fifty-nine percent are female, and the average age is 68 years old. In these birth cohorts, the typical sample member is a high school graduate. Nine percent of the sample is Latino and 16 percent are African-American reflecting over-samples of both groups in the HRS.

On average, HRS respondents remembered half of the ten words spoken to them in immediate and delayed recall with two-thirds of the sample being able to recall between 3 and 7 words. HRS respondents were able to correctly compute only a bit more than one answer correctly in the three question numeracy sequence. The experimental HRS measures of number series and retrieval fluency are both calculated as W scores (McArdle \& Woodcock, 1997). Each $\mathrm{W}$ score is artificially centered at 500 based on the 10 year olds in the norming sample. The $\mathrm{W}$ scoring metric is used so that the change in the probability of getting an item right increases by twenty-five percent for every ten point change in the W score. In this W score metric, the resulting average of number series and retrieval fluency are slightly below 500 and distribution in scores are approximately normal.

We estimate models for three financial outcomes at the individual level: total household wealth, total financial wealth, and the fraction of financial wealth held in stocks. These models 
are estimated both in level form (in 2006) in Table 2.A and as changes from a year 2000 base in Table 2.B. The estimated coefficients and associated ' $t$ ' statistics based on robust standard errors are also listed in these Tables. Non-cognition variables included in these models are standard: gender of the respondent $(1=$ female), race $(1=$ African-American $)$, Hispanic ( $1=$ Latino), a quadratic in age, marital status (married=1), a quadratic in household income, and years of schooling. The only non-standard demographic variable is an indicator variable for whether the respondent was the financial respondent- the partner who was most knowledgeable about financial matters and who answered all household level financial questions in the HRS survey.

The full set of available cognition variables is included in all models. As described above, some cognition variables such as number series and retrieval fluency are only present in experimental modules and administered to about one thousand respondents in each wave. Other cognition variables such as memory recall, mental status (TICS items), and numeracy were given to all HRS respondents. Missing value indicators are included in all models for people who either did not answer or who were not asked specific questions involved in the construction of the right hand side variables. By design, the large proportion of missing values for the number series and retrieval fluency measures in the experimental modules are missing at random.

Results obtained in the 2006 level analysis for non-cognitive variables, presented in Table 2.A, are consistent with those widely reported in the literature (Smith, 1995). Wealth levels, both total and financial, are higher for couples than for single person households, are lower for minorities, increases at a decreasing rate with age, rises steeply with education and with family income but with the latter at a decreasing rate. Individuals with higher education, income, and wealth hold more of their financial wealth in stock while minorities hold less in this more risky asset even at the same age, income, and wealth. 
Our main interest in this paper centers on estimated impacts of cognitive variables. The strongest and most consistent results obtained were for the numeracy and memory recall cognition measures. Answering each question correctly in the three question numeracy sequence is associated with a $\$ 20,000$ increase in total household wealth and about a seven thousand dollar increase in total financial wealth. Enhanced numeracy is also associated with a larger fraction on the financial portfolio held in stocks. All these results are strongly statistically significant.

Similarly, improved episodic memory is associated with higher levels of household and financial wealth but not with how risky (stock intensive) the financial asset portfolio is. While it is difficult to compare units across cognitive measures, these results imply that remembering three additional words in the word recall is associated with total household wealth equivalent to answering one additional question correctly in the numeracy sequence. Our three other cognitive measures- number series, TICS mental status, and retrieval fluency are not consistently related to these financial outcomes. Part of the lack of statistical significance for number series and retrieval fluency may well be due to the lower effective sample size for those measures.

The extreme degree of heterogeneity and right skewness in financial outcomes implies that estimated mean effects may not characterize many individuals in the sample. With that caution in mind, Table 3.A (for total household wealth) and Table 4.A (for total financial wealth) lists estimates from quantile regressions, estimated for the first and third quartile, the median and the $90^{\text {th }}$ percentile. As expected, estimated effects of most of the non-cognitive variables increase as we move up towards higher quantiles in the total wealth and non-financial wealth distribution.

Numeracy, the key cognitive variable identified in Table 2.A, behaves precisely this wayestimated impacts of numeracy increase as we move up the total wealth quantiles- from an estimated impact of $\$ 2.6 \mathrm{~K}$ at the first quartile, to almost $\$ 12 \mathrm{~K}$ for the median household, and 
$\$ 52 \mathrm{~K}$ at the $90^{\text {th }}$ percentile. A similar pattern is found in Table 4.A when the outcome is total financial wealth. The other key variable, episodic memory, does the same but at a far less dramatic rate. Especially for total financial wealth, the estimated impacts of episodic memory are fairly uniform across these percentiles. Compared to Numeracy, episodic memory may be relatively more important at lower values in the wealth distribution.

The results summarized thus far pertain to wealth levels and composition in calendar year 2006. The panel nature of HRS allows us to examine the association of these cognition measures with changes in wealth observed for individuals in the panel. Tables 2.B, 3.B, and 4.B list results obtained from models where the outcome is the change between years 2006 and 2000 in total wealth, total financial wealth, and the fraction of financial wealth held as stocks. All right hand side variables are the same as in the level analysis, but a control is added for year 2000 total household wealth or financial wealth depending upon the financial outcome under investigation.

Not surprisingly, estimated effects of all non-cognitive variables are similar to those obtained from the 2006 level analysis but are much smaller in magnitude since now we are predicting changes between the 2006 and 2000 HRS waves. In particular, numeracy and word recall are consistency related to wealth increases over this six year period while the estimated impacts of the other cognitive variables are quite weak. Answering each numeracy question correctly is associated with an $\$ 8,000$ increase in total household wealth.

\section{Individual level Analysis in CogEcon}

The data used in this section are the result of collaboration between the NCGS+HRS Cognition Study and the Cognitive Economics Survey (CogEcon). ${ }^{5}$ A goal of NCGS+HRS is to conduct detailed measurement, through telephone and personal interviewing, of cognitive

\footnotetext{
${ }^{5}$ NCGS+HRS was led by McArdle and CogEcon was led by Willis The design, contents, and field outcomes of CogEcon and NCGS+HRS surveys are described in detail in Fisher and Helppie (2009).
} 
abilities of a sample of older Americans in the same 50-plus age range of the HRS by developing data to help understand the cognitive bases of economic decision making. To do so, a detailed questionnaire containing measures of wealth and portfolio allocation, self-rated and objective measures of financial knowledge, measures of risk tolerance, use of financial advice and other variables were administered by mail and internet survey to participants in the NCGS+HRS.

The combined NCGS+HRS/CogEcon data set provides a combination of psychological and economic measurements on the same people with greater detail than any other data set. The CogEcon survey invited 1,222 individuals members of the NCGS+HRS sample whose cognitive ability were assessed in face-to-face interviews to participate in the CogEcon mail/internet survey. Of these, 985 returned surveys implying a final response rate of $80.6 \%$, including age ineligible spouses. The Cog Econ sample consists of individuals who range in age from 38 to 96 years, with a mean age of 64.0 years.

The telephone component of NCGS+HRS repeats HRS cognition measures (episodic memory, mental status, numeracy and adaptive number series measure) used above. The personal interview is an intensive three hour cognitive measurement of a large number of ability components. These include number series, retrieval fluency, verbal analogies, spatial relations, picture vocabulary, auditory working memory, visual matching, incomplete words, concept formation, calculation, word attack from WJ-III (Woodcock \& Mather, 2001), Vocabulary, Block Design, Similarities, and Matrix Reasoning from the Wechsler Adult Intelligence Scale (WAIS) plus a switching task) and a vigilance task (McArdle \& Woodcock, 1998).

There are advantages and disadvantages of the CogEcon survey. The principal disadvantage is that sample sizes are much lower than in the core HRS, and with outcomes as heterogeneous as wealth that may lead to results that are less robust. The principal advantage is 
that CogEcon is able to measure in far greater depth dimensions of cognition that may be relevant to economic decision making including wealth accumulation. We view the HRS and CogEcon as complimentary sources of relevant information.

Table 5 presents results for three regression prediction models of $\ln$ current wealth based on data from the CogEcon survey $(n=942)$. In all models, the same demographics- age (quadratic), education, couple status, and income (quadratic)- as in the core HRS analysis are included. These results uniformly show significant positive differences in wealth for persons with increased income (up to a point; $t>8$ ), and for persons in intact couples, but no statistically significant independent increments based on age or education. Education does increase wealth in models where we delete all cognition variables.

In the first model in Table 5, these predictions are estimated in tandem with five cognitive variables derived from the telephone testing alone, which also correspond to cognition variables available in the core HRS. In these data, the five cognitive variables improved the prediction with significant positive independent contributions of Episodic Memory $(t>2)$, Numeracy $(t>2)$, and Mental Status $(t>2)$, but neither Retrieval Fluency nor Number Series. These results parallel reasonably well those found for the same set of cognitive constructs using the HRS in Table 2.A.

The Number Series WJ-III test (WJ-III) used to measure Numerical Reasoning was administered in two different forms. The face-to-face test is the standard WJ-III 47 item version presented using standard WJ rules, with an expected internal consistency reliability of $r_{\mathrm{ic}}>.95$ (Woodcock, et al., 2003). The telephone version is a much shorter adaptive form of the same test, where up to six items are presented in 3-5 minutes (McArdle et al., 2009). The items chosen are selected based on prior performances on earlier items (i.e., harder items are selected if the 
participant has given correct answers earlier), with an expected internal consistency reliability of $r_{\text {ic }}>$.85. In the CogEcon study (NGCS+HRS) the participants were administered the telephone test first and then administered the face-to-face test in standard testing conditions from one to 14 days later. After taking into account some expect differences due to time-lags, the average testretest correlation was $r_{\mathrm{tr}}>0.72$ (McArdle et al., 2009).

The second model in Table 5.A substitutes the longer (and more reliable) face-to-face Number Series test for the telephone version used in the first model. The face to face version of the number series score now offers a strong incremental prediction $(t>3)$, and reduces- but does not eliminate- the estimated effects of numeracy and episodic memory..

In the third model of Table 5.A three new cognitive tests are added-calculation- matrix reasoning, and mean financial literacy score. These tests are not currently available in the HRS. WJ-III Calculation is a test of math achievement measuring the ability to perform mathematical computations from Woodcock-Johnson Scales (Woodcock, et al., 2002) with an expected internal consistency reliability of $r_{\mathrm{ic}}>.95$. Initial items in Calculation require an individual to write single numbers. The remaining items require a person to perform addition, subtraction, multiplication, division, and combinations of these basic operations, as well as some geometric, trigonometric, logarithmic, and calculus operations. The calculations involve negative numbers, percents, decimals, fractions, and whole numbers. Because calculations are presented in a traditional problem format in the Test Record form, the person is not required to make any decisions about what operations to use or what data to include. Calculation is similar to numeracy in intent in that they both attempt to measure aspects of Gc applied to numbers.

WASI Matrix Reasoning measures nonverbal fluid reasoning and general intellectual ability from the abbreviated form of the Weschler Adult Intelligence Scale (WAIS-III, Wechsler, 
1999). These 20 items require participants to looks at each set of symbols (arrayed in a vector or matrix) with one missing location, and then they are asked to fill in "the best option for the missing piece." The person is not asked or required to make any decisions about reasons why this choice is best. Given its use of abstract and spatial symbols, matrix reasoning can be thought of as a dimension of Gf.

CogECON Financial Literacy/Financial Sophistication are 24 items (true/false and confidence). These measures signify the belief that these questions have more sensitivity at the "high" end of the scale (when compared to measures in HRS and many other surveys). These questions have two versions each, one which is "true" and one which is "false," but ask a very similar question. True/false measures of financial sophistication are on a scale ranging from $100 \%$ to $50 \%$ confidence that the statement is "false," and $50 \%$ to $100 \%$ confidence that the statement is "true." For example, the "true" version (Q17) is: "An investment advisor tells a 30year-old couple that $\$ 1,000$ in an investment that pays a certain, constant interest rate would double in value to $\$ 2,000$ after 20 years. If so, that investment would be worth $\$ 4,000$ in less than 45 years." The "false" version reads: "An investment advisor tells a 30-year-old couple that $\$ 1,000$ in an investment that pays a certain, constant interest rate would double in value to $\$ 2,000$ after 20 years. If so, that investment would not be worth $\$ 4,000$ for at least 45 years." The italics are added to indicate parts of questions that differ. The respondent is instructed to decide whether the statement is "true" or "false," and to indicate their confidence in this answer.

In the third model in Table 5.A when these additional cognitive tests are added as predictions, Matrix Reasoning is the strongest independent predictor $(t>3)$, Financial Literacy is next $(t>2)$, but the Calculation test is not a statistically significant predictor. All statements about tests of significance must contain the caveat of relatively small sample sizes in CogEcon. 
Including measures of financial literacy in models of wealth accumulation is a bit odd. Financial literacy is not manna from heaven enabling one to successfully navigate the complicated and dangerous waters of financial success. Those with more an interest or opportunity to invest in financial markets have more of an incentive to invest in acquiring the knowledge of how to successfully operate in these markets or to become financially literate. This view argues that models in Table 5.A have it all wrong and that financial literacy is an outcome that should be studied. Table 5.B does just that by predicting levels of financial literacy with the same set of personal attributes and set of cognitive variables discussed earlier.

Financial literacy increases with age and with income but at a decreasing rate and increases with years of schooling. All these predictive effects are statistically significant. Once again, intact mental status (the TICS score) and retrieval fluency appear to be aspects of cognition that are not related to financial decision making. In contrast, all aspects of cognition related to numerical ability-number series, numeracy, and calculation- are all strongly predictive of better financial literacy. These results point to one possible pathway through which cognitive ability related to numbers may promote wealth accumulation- making it easier to acquire relevant financial knowledge. It also suggests that we may be over-controlling by including financial literacy in the models in Table 5.A as this may suppress the effects of cognition. The final model in Table 5.A removes the financial literacy variable. Estimated effects of both the number series and calculation are increased by its removal.

These new results broadly highlight the fact that the individual cognition tests can add to the individual level descriptive predictions of our basic understanding of differences in wealth. There appear to be independent benefits of having both higher Financial Literacy (i.e., Gc) and higher ability to reason in a non-quantitative fashion (i.e., Gf). 


\section{Spousal level Analysis in the HRS}

One analytical advantage of HRS is that interviews are conducted with both spouses and/or partners in the household. Thus, information is provided separately by both parties on dimensions of their own cognition (the same ones measured in the core interview) alongside the common household data on their wealth holdings and income and their own personal attributes. This allows an examination of the extent to which cogitative attributes of both spouses predict household wealth holdings and whether cognition of one spouse is more important than the other at least for financial outcomes. To do so, a sample of married couples is used in this analysis.

Figure 2 plots total household wealth against numeracy scores of the husband and wife. Household wealth increases sharply as either score rises with large differences between those couples who achieve a perfect score compared to those who collectively get the lowest score of zero correct answers. When both spouses answer all questions correctly, wealth is 1.7 million dollars- when neither answer any question correctly household wealth is about two hundred thousand dollars. Wealth tends to increase with a higher numeracy score of either spouse.

Table 6 examines the relationship of numeracy scores of both spouses with total household and financial wealth, and the fraction of financial wealth held in stock. In this table, for reasons that will be apparent below, data are arrayed by financial and non-financial respondents. All three wealth outcomes increase sharply with numerical scores of both financial and non-financial respondents. If both scores are zero (about ten percent of cases), total wealth is two hundred thousand dollars. For families where both spouses get all numeracy questions correct, total household wealth is more than eight times higher- 1.7 million dollars. Wealth is higher when the numeracy scores of both financial and non-financial respondents are higher. 
A similar but even more dramatic pattern exists for total financial wealth. For families where both spouses score three on the numeracy question, financial wealth is ten times larger than if both got all numeracy questions incorrect. There is a tendency for numeracy of the financial respondent to matter more since in four of the six off-diagonal pairs, financial wealth is larger if the higher numeracy score is that of the financial respondent. We will return to this issue below when discussing model estimates.

Our final measure is the fraction of financial assets held in stocks where one may think a priori that financial numeracy may matter more. Once again there is evidence of sharp increases in the percent of the financial portfolio held in stocks as the numeracy score of each spouse rises.

One important issue is whether finances are related symmetrically to cognitive ability of each spouse. In many households especially older ones in the HRS age range, there is almost complete specialization in financial decision making with one spouse in charge of most of the calls. In such a situation, one would think or hope that the cognitive ability of the financial decision maker may matter more for household wealth outcomes. To investigate this possibility, we arrayed the data for our all cognitive measures in two different ways in Table 7- by gender and by the financially knowledgeable person in the household.

Consider the stratification by male and female or equivalently husband and wife. With the exception of memory recall (higher for women), numeracy (higher for men) and to a lesser extent number series (higher for men), average differences between the other cognitive measures are all small. When we shift instead to comparison between financial and non-financial respondents, there is a more pronounced shift in favor of the financial respondent with the sole exception of retrieval fluency which is the same for both financial and non-financial respondents. 
The bottom panel of Table 7 stratifies by gender and whether one is a financial respondent. For women, there is little difference in cognitive scores between those who are and are not financial respondents. In contrast, for men, and again with the exception of retrieval fluency, male financial respondents appear to have higher cognitive ability than male nonfinancial respondents. One interpretation consistent with these data is that men are the default option for financial decision-making in the family unless poor cognitive abilities get in the way.

Table 8 presents the correlation matrix of full set of cognitive variables for husbands and wives. This table illustrates one current problem with cognitive variables available in HRS for spousal level analysis. Cognitive variables in experimental modules only- number series and retrieval fluency-are randomly assigned to only 1200 respondents. The probability that both partners are assigned these cognitive modules is low, and relatively few HRS couples have them for both partners. This spousal analysis is limited to the three cognitive measures in the core.

There are two salient patterns. First, when available, correlation in scores within gender across cognitive measures is low and the correlation across husbands and wives within a cognitive measure is also low. The only noticeable exception to that across spouses are mental status (0.50) and to a lesser extent numeracy (0.23). Within person, episodic memory and numeracy are correlated ( 0.57 for husbands and 0.43 for wives).

Table 9.A presents results for estimates of relationship between cognitive attributes of both spouses and the three financial outcomes for the household. These models are estimated over a sample of married couples. The other covariates include the same attributes included in the individual model discussed above with the addition of an age quadratic for the spouse and spousal education. Coefficients on the non-cognitive variables are similar to those discussed above in the individual model and no new issues are raised in this couples sample. 
Once again, there is scant evidence of any systematic relation for the TICS mental status measure for either spouse. With the exception of total wealth measure (where estimate effects are higher for non-financial respondents), word recall has similarly estimated impacts for both financial and non-financial respondents. The critical distinction relates to our numeracy measure where estimated effects for financial respondents are three times larger than numeracy of nonfinancial respondents. Consistent with the relative magnitude of these estimated impacts, the evidence above indicated that families selected the spouse with the higher cognitive measure of numeracy as the financial respondent.

Table 9.B contains the couple analysis when the outcome is the change in wealth between 2006 and 2000. For the two cognitive measures that matter-word recall and numeracy- estimated impacts are once again much larger when it is a trait of the financial respondent. For total wealth, the impact of numeracy of the financial respondent is seven times larger than numeracy of the non-financial respondent.

Similar to the corresponding individual level models, Tables 10 and 11 presents quantile models for total household wealth and total financial wealth for the couples's sample. As before, we find increasing impacts of numeracy as we move to higher percentiles in the wealth distribution. This increase is even steeper for numeracy of the financial respondent implying that the much lower estimated impact of numeracy for the non-financial respondent is particularly the case at higher levels of wealth. This is even more so when we examine total household financial wealth as the economic outcome.

\section{Who is the Financial Respondent?}

These results indicating a strong association of education and dimensions of cognition with financial outcomes of the family and the dominance of male attributes raise an issue of how 
the family decides who shall be the financial respondent. HRS asks the family to reveal who is the most knowledgeable financial person- the husband or the wife- and that person answers all financial questions about family income and wealth holdings. It seems reasonable that the selected person had the major role in financial decision making for the family. What are the traits of both partners that influence this choice?

Table 12.A lists the percent of cases for married couples where the husband is selected as the financial respondent, stratified by age of both husbands and wives. In sixty-two percent of households, men are the financial respondent indicating a strong tilt towards men at least in these birth cohorts. This male preference is particularly pronounced when the husband is much older than his wife. To illustrate, in marriages with husbands in their seventies with wives who are at least ten years younger, in $82 \%$ of the cases men are financial respondents. Especially when wives are young, the selection of males as financial respondents increases sharply as men are older. Conditional, on husbands' age, the probability of selecting women as the financial respondent increases with wives' age but the age gradients are not as dramatic.

Table 12.B arrays the same data but now stratified by education of both spouses. Increases in education of either spouse raise the probability of being selected as the financial respondent. Education is more sharply graded than age and husbands' education has a larger impact than that of his spouse. If the husband is a college graduate, the odds are more than three to one that he will be the financial respondent no matter what the education of the wife is.

Table 13 presents a multivariate model where the outcome is one if men are the financial respondent and zero otherwise. The only variable measured at the household level is a quadratic in household income. All other variables are individual attributes of husbands and wives and include age dummies, education, and the three cognition variables. Since the complement of men 
being the financial respondent is that women perform those duties, the effects of all variables for women being the financial respondent are exactly the same with a reversal of sign. The final column in Table 13 provides a statistical test $(\mathrm{F})$ for whether the absolute value of the coefficients of wives and husbands attributes are the same for all individual level variables.

Total family income is not a strong predictor of whom the financial respondent is suggesting that this choice rests more on cognitively related attributes and societal norms. Age coefficients (with $80+$ as the omitted class) suggest even more strongly than the cross-tabs in Table 12.A did the presence of emerging cohort effects loosening male preference in these decisions. This may be more so for younger cohorts than those represented in the HRS. Effects of education and all three cognitive variables are statistically significant for both spouses, but are always quantitatively larger for husbands than for wives. While all cognition and education variables and the differences in size of impact between wives and husbands are statistically significant, impacts of numeracy are particularly strong for both marriage partners. In general, the estimated impact of wives' cognition variables are at least half that of their husbands.

\section{Conclusions}

Inclusion of individual cognitive measures in prediction of economic outcomes has turned out to be useful. While the importance and the pattern of effects needs to consider the specific sources of information (i.e., the entire HRS, individual modules, or CogEcon), these cognitive measures appear to meet minimal standards of being descriptively informative.

Numeracy, as measured by answers to three simple mathematical questions, is by far the most predictive of wealth among all cognitive variables in the HRS sample. This is thought by cognitive psychologists to be a direct measure of a specific and practical form of numerical knowledge (i.e., a form of Crystallized Intelligence). We found independent impacts which were 
statistically significant for all three financial outcomes and for financial and non-financial respondents alike. Perhaps more importantly, the estimated impact of answering a question correctly is much higher for the financial respondent compared to non-financial respondents in all three outcomes. To illustrate, the estimated effect of answering a question correctly is thirty thousand dollars greater household wealth for the financial respondent and only ten thousand dollars if one is the non-financial respondent. Numeracy had more of a problem maintaining statistical significance in the CogEcon sample when tested against other more complex and time intensive measures (number series and calculation) that in part attempt to measure similar things. Still, one has to be impressed with the ability of the three simple questions in the numeracy sequence to capture the core elements in predicting wealth accumulation.

The independent impact of number series has similar characteristics in its relationship to the financial outcomes, but these relationships are not as important with the strong qualification that there currently exists more limited data on this measure in the HRS. The number series is not simply a measure of numerical knowledge, but is a broader measure of numerical reasoning (i.e., an indicator of Fluid Intelligence), and this is not a pure indicator of the acquisition of wealth. The more complicated and time intensive measurement of number series in the face to face component of the CogEcon sample does considerably better in predicting wealth.

Episodic memory (or word recall) also appears to be related to the total and financial wealth holdings of the family and in this case it applies to both the financial and non-financial respondent. The remaining two cognitive measures- mental status and retrieval fluency- have very weak and erratic relationships with these financial outcomes. Mental status is statistically significant in only two of six cases and retrieval fluency in only one of six cases. ${ }^{6}$

\footnotetext{
${ }^{6}$ Remember that retrieval fluency is only available in an experimental module in the 2006 wave so that statistical significance is a more difficult hurdle for this variable.
} 
Although these specific cognitive measures were useful in predictions of measures of accumulated wealth, it is certainly possible that other financial outcomes will be better predicted by different indicators of cognitive functions. Additional analyses of HRS data and other data can be conducted using this basic approach, including cognitive speed measures and all available cognitive measures for different outcomes.

The type of unabashedly exploratory and descriptive analysis in this paper cannot establish causal pathways for these associations. There is no randomization in the cognitive ability of HRS respondents and one can easily think of correlates of these cognitive measures that may offer plausible reasons for these associations. Nor can it be easily dismissed that a history of lifetime interests and investments in the stock market for example could lead to improved numerical ability. Yet, the presence of these estimated effects of numeracy on total and financial wealth at lower wealth quartiles where levels of commitment of investors is relatively modest should caution at least against a purely reverse pathway from investments to cognitive ability. For some cognitive functions, such as numerical ability, the cognitive training of these skills seem to be readily attainable by most persons, and the returns seem high. At a minimum, the type of strong associations in descriptive analysis in this paper is a signal that one may want to pursue studies that may offer more discriminating tests of whether these associations can be thought of as plausibly causal. 


\section{References}

Banks, James and Zoë Oldfield. (2007). Understanding Pensions: Cognitive Function, Numerical Ability and Retirement Saving. FISCAL STUDIES, vol. 28, no. 2, pp. 143170. $0143-5671$

Benjamin, D. J., Brown, S. A. and Shapiro, J. M. (2006), 'Who is "behavioural”? Cognitive ability and anomalous preferences', http://ssrn.com/.

Ben-Porath, Yoram. (1967) The Production of Human Capital and the Life Cycle of Earnings. The Journal of Political Economy, Vol. 75, No. 4, Part 1, pp. 352-365

Cattell, R. B. (1987). Intelligence: Its structure, growth, and action. New York: Elsevier Science Pub. Co.

Cunha, F. and Heckman, James. , (2007) "The Technology of Skill Formation," American Economic Review, 97(2):31-47.

Delevande, Adeline, Susann Rohwedder and Robert J. Willis (2008) "Preparation for Retirement, Financial Literacy and Cognitive Resources.” Michigan Retirement Research Center Working Paper 2008-190

Eichorn, D. H., Clausen, J. A., Haan, N., Honzik, M. P., \& Mussen, P. (Eds.). (1981). Present and past in middle life. New York: Academic Press.

Elder, G. H., Jr. (1974). Children of the Great Depression. Chicago, IL: University of Chicago Press.

Farias, S.T., Mungas, D. Reed, B.R., Cahn-Weiner, D., Jagust, W., Baynes, K., \& DeCarli, C. (2008). The measurement of everyday cognition (ECog): Scale development and psychometric properties. Neuropsychology, 22 (4), 531-544.

Fisher and Helppie, (2009) "Cognitive Economics Survey Study and Data Documentation." Survey Research Center, University of Michigan (January 9, 2009)

Harden, K.P., Turkheimer, E., \& Loehlin, J.C. (2007). Genotype by environment interaction in adolescents' cognitive aptitude. Behavior Genetics, 37, 273-283.

Hershey. D.A., Jacobs-Lawson, J.M., McArdle, J.J., \& Hamagami, F. (2007). Psychological foundations of financial planning. Journal of Adult Development, 14, 26-36.

Herzog, A. R., \& Rodgers, W. L. (1999). Cognitive performance measures in survey research on older adults. In N. Schwarz, D. Park, B. Knauper, \& S. Sudman (Eds.), Aging, cognition, and self-reports (pp. 327-340). Philadelphia, PA: Psychology Press. 
Herzog, A. R., \& Wallace, R. B. (1997). Measures of cognitive functioning in the AHEAD study [Special Issue]. Journal of Gerontology Series B: Psychological Sciences and Social Sciences, 52B, 37-48.

Horn, J. L. and McArdle, J.J. (2007). Understanding human intelligence since Spearman. In R. Cudeck \& R. MacCallum, (Eds.). Factor Analysis at 100 years (pp. 205-247). Mahwah, NJ: Lawrence Erlbaum Associates, Inc.

Juster, F. Thomas and James P. Smith. "Improving the Quality of Economic Data: Lessons from HRS and AHEAD," Journal of the American Statistical Association 92(440):1268-1278, December 1997

Juster, F. Thomas, James P. Smith, and Frank Stafford. "The Measurement and Structure of Household Wealth,” Labour Economics 6(2):253-275, June 1999.

Klebanov, P.K., Brooks-Gunn, J. McCarton, C. \& McCormick, M.C. (1998) Child Development, $69,1420-1436$.

Lee, S., Kawachi, I., Berkman, L. F., \& Grodstein, F, (2003). Education, Other Socioeconomic Indicators, and Cognitive Function. American Journal of Epidemiology. 157(8):712720.

McArdle, J. J., Ferrer-Caja, E., Hamagami, F., \& Woodcock, R. W. (2002). Comparative longitudinal structural analyses of the growth and decline of multiple intellectual abilities over the life span. Developmental Psychology, 38(1), 115-142.

McArdle, J.J., Fisher, G.G. \& Kadlec, K.M. (2007). Latent Variable Analysis of Age Trends in Tests of Cognitive Ability in the Health and Retirement Survey, 1992-2004. Psychology and Aging, 22 (3), 525-545.

McArdle, J.J. \& Woodcock, R.W. (Eds., 1998). Human Abilities in Theory and Practice. Mahwah, NJ: Erlbaum.

Ofstedal, Mary Beth, Fisher, Gwenith G. and Herzog, A. Regula. "Documentation of Cognitive Functioning Measures in the Health and Retirement Study." HRS Documentation Report DR-006 March 2005.

Parker, A. M. and Fischhoff, B. (2005), 'Decision-making competence: external validation through an individual-differences approach', Journal of Behavioral Decision Making, vol. 18, pp. 1-27.

Peters, E., Västfjäll, D., Slovic, P., Mertz, C. K., Mazzocco, K. and Dickert, S. (2006), 'Numeracy and decision making', Psychological Science, vol. 17, pp. 407-13.

Ramey, S.L., Sackett, G.P., Sameroff, A.J., Lewis, M., Miller, S.M. (2000). The early 
caregiving environment; Expanding views on nonparental care and cumulative life experiences. Handbook of Developmental Psychopathology (2nd ed.). Dordrecht, Netherlands: Kluwer Academic Publishers, pp. 365-380.

Rutter, M. (1985). Family and school influences on cognitive development. Journal of Child Psychology and Psychiatry, 26, 683-704.

Smith, James P. "Racial and Ethnic Differences in Wealth in the Health and Retirement Study," Journal of Human Resources 30:S158-S183, December 1995

Smith, James P. "Inheritances and Bequests," in James P. Smith and Robert Willis (eds.), Wealth, Work, and Health: Innovations in Measurement in the Social Sciences, University of Michigan Press, 1999, pp. 121-149.

Turkheimer, E., Haley, A., Waldron, M., D’Onofrio, B., \& Gottesman, I.I. (2003). Socioeconomic status modifies heritability of IQ in young children. Psychological Science, 6, 623-628.

Willis, Robert J. (2007) “Cognitive Economics and Human Capital,” Presidential Address to Society of Labor Economists, Chicago, May 4-5, 2007. 
Table 1

Means and Standard Deviations

\begin{tabular}{lrrr}
\hline Variable & Mean & Median & Standard Dev \\
\hline Total household wealth $^{\mathrm{a}}$ & & & \\
Total financial wealth $^{\mathrm{a}}$ & 498.9 & 198.0 & $1,228.83$ \\
\% of financial wealth in stocks $^{\text {\% Couples }}$ & 312.7 & 55.9 & $1,039.9$ \\
Total income & 8.96 & 0.0 & 20.86 \\
Female & 0.65 & $\mathrm{NA}$ & 0.487 \\
Hispanic & 62.18 & 37.00 & 173.22 \\
Non-white & 0.589 & $\mathrm{NA}$ & 0.492 \\
Education & 0.093 & $\mathrm{NA}$ & 0.290 \\
Age & 0.163 & $\mathrm{NA}$ & 0.369 \\
& 12.31 & 12.00 & 3.40 \\
Cognition Variables & 68.0 & 68.0 & 11.1 \\
Number Series (W-scale) & & & \\
TICS Mental Status (0-10) & & & \\
Word Recall (0-10) & 498.8 & 507.5 & 40.2 \\
Numeracy & 8.85 & 10.00 & 2.16 \\
Retrieval Fluency (W-scale) & 4.85 & 5.00 & 1.73 \\
& 1.19 & 1.00 & 0.90 \\
\hline
\end{tabular}

\footnotetext{
${ }^{a}$ thousands of dollars

b- defined over cases asked the cognition questions
} 
Table 2.A

Relationship of Household Wealth Holdings to Cognition

2006 Individual Sample-Robust Regression

(wealth in thousands of dollars)

\begin{tabular}{lrrrrrr}
\hline & \multicolumn{2}{c}{ Total Wealth } & \multicolumn{2}{c}{ Total Financial Wealth } & \multicolumn{2}{c}{ Percent in Stock } \\
& Coef. & $\mathrm{t}$ & Coef. & $\mathrm{t}$ & $\mathrm{C}$ Cof. & $\mathrm{t}$ \\
\hline & & & & & & \\
Female & 5.04 & 1.39 & -0.69 & 0.46 & 0.63 & 1.72 \\
Hispanic & -7.44 & 1.21 & -16.48 & 6.46 & -1.61 & 2.43 \\
Non-white & -60.23 & 12.86 & -24.71 & 12.71 & -3.36 & 6.68 \\
Age & 18.13 & 11.21 & 6.13 & 9.13 & -0.59 & 3.47 \\
Age squared & -0.10 & 9.16 & -0.03 & 7.22 & 0.01 & 5.54 \\
Couple & 52.01 & 11.96 & 14.38 & 7.97 & -0.16 & 0.36 \\
Education & 10.94 & 18.08 & 3.86 & 15.35 & 1.00 & 15.71 \\
Fin resp & -20.74 & 5.02 & -7.96 & 4.64 & -1.24 & 3.01 \\
Total income & 2.20 & 109.0 & 0.76 & 90.06 & 0.01 & 5.47 \\
Income squared & -0.000 & 66.63 & -0.000 & 58.55 & $-1.02 \mathrm{e}-06$ & 5.83 \\
& & & & & & \\
Cognition Variables & & & & & & \\
Number Series W & 0.14 & 1.19 & 0.03 & 0.67 & 0.02 & 1.26 \\
TICS Mental Status & 2.41 & 2.26 & 0.34 & 0.77 & -0.02 & 0.14 \\
Word Recall & 7.63 & 6.67 & 3.77 & 7.92 & 0.17 & 1.47 \\
Numeracy & 20.09 & 8.92 & 7.38 & 7.89 & 1.65 & 7.23 \\
Retrieval Fluency W & 0.59 & 1.18 & 0.42 & 1.99 & -0.07 & 1.33 \\
Total wealth & & & & & 0.002 & 15.39 \\
Cons & -1206.59 & 4.62 & -512.56 & 4.73 & 28.83 & 1.09 \\
N & 18,382 & & 18,382 & & 16,220 & \\
\hline
\end{tabular}


Table 2.B

Relationship of Change in Household Wealth Holdings (2006-2000) to Cognition 2006 Individual Sample-Robust Regression

(wealth in thousands of dollars)

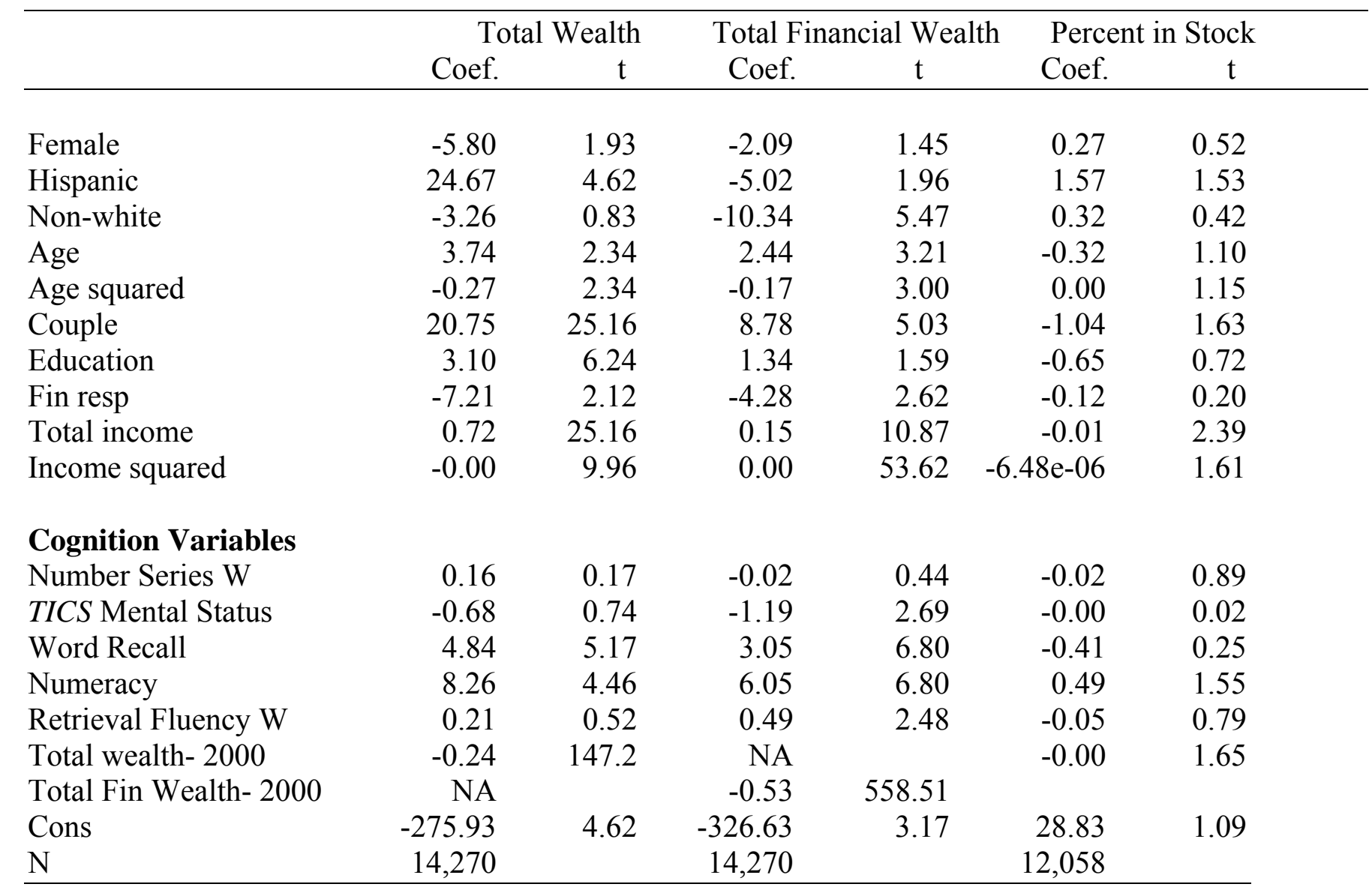

NA- not applicable 
Table 3.A

\section{Relationship of Total Household Wealth Holdings to Cognition 2006 Individual Sample-Quantile Models (wealth in thousands of dollars)}

\begin{tabular}{|c|c|c|}
\hline & \multicolumn{2}{|c|}{$25^{\text {th }}$ Quantile } \\
\hline & Coef. & $\mathrm{t}$ \\
\hline Female & 6.130 & 2.65 \\
\hline Hispanic & -2.244 & 0.56 \\
\hline Non-white & -23.415 & 7.62 \\
\hline Age & 13.050 & 13.53 \\
\hline Age squared & -0.075 & 11.11 \\
\hline Married & 31.281 & 11.16 \\
\hline Education & 4.530 & 12.30 \\
\hline Financial respondent & -10.263 & 3.87 \\
\hline Income & 1.914 & 127.99 \\
\hline Income squared & -0.000 & 87.63 \\
\hline Number Series W & 0.093 & 1.27 \\
\hline TICS Mental Status & 0.497 & 0.75 \\
\hline Word Recall & 4.758 & 6.64 \\
\hline Numeracy & 12.078 & 8.49 \\
\hline Retrieval fluency W & 0.571 & 1.84 \\
\hline Cons & -951.354 & 5.90 \\
\hline \multirow[t]{3}{*}{$\mathrm{N}$} & 18,382 & \\
\hline & \multicolumn{2}{|c|}{$90^{\text {th }}$ Quantile } \\
\hline & Coef. & $\mathrm{t}$ \\
\hline Female & 14.393 & 0.92 \\
\hline Hispanic & -40.208 & 1.66 \\
\hline Non-white & -182.266 & 9.81 \\
\hline Age & 32.186 & 4.08 \\
\hline Age squared & -0.173 & 3.18 \\
\hline Married & 59.891 & 3.17 \\
\hline Education & 23.883 & 8.00 \\
\hline Financial respondent & -58.543 & 3.30 \\
\hline Income & 12.093 & 148.76 \\
\hline Income squared & -0.001 & 136.52 \\
\hline Number Series W & 0.453 & 0.82 \\
\hline TICS Mental Status & 4.614 & 0.93 \\
\hline Word Recall & 6.892 & 1.36 \\
\hline Numeracy & 76.988 & 7.72 \\
\hline Retrieval Fluency W & 1.935 & 0.89 \\
\hline Cons & -2613.225 & 2.28 \\
\hline $\mathrm{N}$ & 18,382 & \\
\hline
\end{tabular}


Table 3.B

Relationship of Changes in Total Household Wealth Holdings (2006-2000) to Cognition 2006 Individual Sample-Quantile Models

(wealth in thousands of dollars)

\begin{tabular}{|c|c|c|}
\hline & \multicolumn{2}{|c|}{$25^{\text {th }}$ Quantile } \\
\hline & Coef. & $\mathrm{t}$ \\
\hline Female & 0.183 & 0.09 \\
\hline Hispanic & 3.803 & 1.01 \\
\hline Non-white & -4.677 & 1.66 \\
\hline Age & 6.472 & 6.05 \\
\hline Age squared & -0.046 & 5.86 \\
\hline Married & 17.408 & 6.67 \\
\hline Education & 1.210 & 3.57 \\
\hline Financial respondent & -4.9940 & 2.07 \\
\hline Income & 0.881 & 43.44 \\
\hline Income squared & -0.000 & 14.76 \\
\hline Number Series W & 0.024 & 0.37 \\
\hline TICS Mental Status & -0.905 & 1.43 \\
\hline Word Recall & 3.257 & 4.99 \\
\hline Numeracy & 7.968 & 6.15 \\
\hline Retrieval fluency W & 0.342 & 1.29 \\
\hline Wealth 2000 & -0.573 & 414.48 \\
\hline Cons & -439.476 & 3.14 \\
\hline \multirow[t]{3}{*}{$\mathrm{N}$} & 14,272 & \\
\hline & \multicolumn{2}{|c|}{$90^{\text {th }}$ Quantile } \\
\hline & Coef. & $\mathrm{t}$ \\
\hline Female & -4.452 & 0.54 \\
\hline Hispanic & 66.162 & 4.50 \\
\hline Non-white & 7.984 & 0.75 \\
\hline Age & -7.326 & 1.60 \\
\hline Age squared & -0.057 & 1.72 \\
\hline Married & 29.766 & 2.97 \\
\hline Education & 6.974 & 4.54 \\
\hline Financial respondent & -3.660 & 0.38 \\
\hline Income & 3.404 & 45.14 \\
\hline Income squared & -0.002 & 27.38 \\
\hline Number Series W & 0.102 & 0.40 \\
\hline TICS Mental Status & -5.912 & 2.36 \\
\hline Word Recall & 2.149 & 0.84 \\
\hline Numeracy & 24.624 & 4.71 \\
\hline Retrieval Fluency W & 3.352 & 2.69 \\
\hline Wealth 2000 & 0.401 & 139.79 \\
\hline Cons & -1447.415 & 2.23 \\
\hline $\mathrm{N}$ & 14,272 & \\
\hline
\end{tabular}


Table 4.A

Relationship of Total Financial Wealth Holdings to Cognition 2006 Individual Sample-Quantile Models

(wealth in thousands of dollars)

\begin{tabular}{|c|c|c|}
\hline & \multicolumn{2}{|c|}{$25^{\text {th }}$ Quantile } \\
\hline & Coef. & $\mathrm{t}$ \\
\hline Female & 0.894 & 1.27 \\
\hline Hispanic & -3.196 & 2.58 \\
\hline Non-white & -7.863 & 8.39 \\
\hline Age & 4.422 & 15.15 \\
\hline Age squared & -0.026 & 12.88 \\
\hline Married & -0.213 & 0.25 \\
\hline Education & 0.739 & 6.48 \\
\hline Financial respondent & -2.649 & 3.28 \\
\hline Income & 0.825 & 207.93 \\
\hline Income squared & -0.000 & 160.79 \\
\hline Number Series W & 0.005 & 0.21 \\
\hline TICS Mental Status & -0.179 & 0.89 \\
\hline Word Recall & 0.906 & 4.15 \\
\hline Numeracy & 2.605 & 6.00 \\
\hline Retrieval Fluency W & 0.179 & 1.95 \\
\hline Cons & -285.730 & 5.95 \\
\hline \multirow[t]{3}{*}{$\mathrm{N}$} & 18,382 & \\
\hline & \multicolumn{2}{|c|}{$90^{\text {th }}$ Quantile } \\
\hline & Coef. & $\mathrm{t}$ \\
\hline Female & 5.737 & 0.57 \\
\hline Hispanic & -47.886 & 3.14 \\
\hline Non-white & -114.563 & 9.65 \\
\hline Age & 19.143 & 3.85 \\
\hline Age squared & -0.099 & 2.87 \\
\hline Married & 6.725 & 0.55 \\
\hline Education & 13.375 & 7.05 \\
\hline Financial respondent & -39.262 & 3.44 \\
\hline Income & 9.898 & 173.15 \\
\hline Income squared & -0.001 & 165.84 \\
\hline Number Series W & 0.173 & 0.50 \\
\hline TICS Mental Status & 0.015 & 0.00 \\
\hline Word Recall & 2.350 & 0.73 \\
\hline Numeracy & 52.309 & 8.13 \\
\hline Retrieval Fluency W & 2.356 & 1.63 \\
\hline Cons & -2105.232 & 2.77 \\
\hline $\mathrm{N}$ & 18,382 & \\
\hline
\end{tabular}


Table 4.B

Relationship of Changes (2006-2000) in Total Financial Wealth Holdings to Cognition 2006 Individual Sample-Quantile Models

(wealth in thousands of dollars)

\begin{tabular}{|c|c|c|}
\hline & \multicolumn{2}{|c|}{$25^{\text {th }}$ Quantile } \\
\hline & Coef. & $\mathrm{t}$ \\
\hline Female & -0.186 & 0.307 \\
\hline Hispanic & 0.348 & 0.31 \\
\hline Non-white & -4.119 & 4.99 \\
\hline Age & 1.361 & 4.29 \\
\hline Age squared & -0.010 & 4.26 \\
\hline Married & 1.484 & 1.95 \\
\hline Education & 0.214 & 2.13 \\
\hline Financial respondent & -0.835 & 1.19 \\
\hline Income & 0.249 & 38.60 \\
\hline Income squared & 0.000 & 17.81 \\
\hline Number Series W & 0.007 & 0.35 \\
\hline TICS Mental Status & -0.531 & 2.87 \\
\hline Word Recall & 0.741 & 3.88 \\
\hline Numeracy & 1.743 & 4.60 \\
\hline Retrieval Fluency W & 0.162 & 2.08 \\
\hline Financial Wealth-2000 & -0.708 & 1530.60 \\
\hline Cons & -134.091 & 3.25 \\
\hline \multirow[t]{3}{*}{$\mathrm{N}$} & 14,272 & \\
\hline & \multicolumn{2}{|c|}{$90^{\text {th }}$ Quantile } \\
\hline & Coef. & $\mathrm{t}$ \\
\hline Female & 2.887 & 0.55 \\
\hline Hispanic & 1.092 & 0.12 \\
\hline Non-white & -14.561 & 2.29 \\
\hline Age & -3.735 & 1.37 \\
\hline Age squared & 0.033 & 1.65 \\
\hline Married & 14.807 & 2.39 \\
\hline Education & 3.354 & 3.55 \\
\hline Financial respondent & -2.229 & 0.38 \\
\hline Income & 2.771 & 59.78 \\
\hline Income squared & -0.001 & 30.78 \\
\hline Number Series W & 0.105 & 0.62 \\
\hline TICS Mental Status & -2.018 & 1.30 \\
\hline Word Recall & 0.610 & 0.37 \\
\hline Numeracy & 10.426 & 3.16 \\
\hline Retrieval Fluency W & 2.243 & 2.98 \\
\hline Financial Wealth 2000 & 0.359 & 142.31 \\
\hline Cons & -1046.97 & 2.67 \\
\hline $\mathrm{N}$ & 14,272 & \\
\hline
\end{tabular}


Table 5.A

Total Wealth Model in the CogEcon Sample

\begin{tabular}{|c|c|c|c|c|c|c|}
\hline & Coef & $\mathrm{t}$ & Coef & $\mathrm{t}$ & Coef & $\mathrm{t}$ \\
\hline \multicolumn{7}{|c|}{ A. Log Wealth } \\
\hline Age & .052 & 0.45 & .047 & 0.41 & .062 & 0.50 \\
\hline Age squared & .000 & 0.22 & .000 & 0.31 & .000 & 0.22 \\
\hline Couple & .979 & 4.14 & .949 & 4.01 & .758 & 3.07 \\
\hline Education & .053 & 1.02 & .017 & 0.32 & -.083 & 1.41 \\
\hline Income & .000 & 8.43 & .000 & 8.26 & .000 & 7.78 \\
\hline Income squared & $-1.93 e-11$ & 7.32 & $-1.87 \mathrm{e}-11$ & 7.08 & $-1.80 \mathrm{e}-11$ & 6.82 \\
\hline \multicolumn{7}{|l|}{ Cognition Variables } \\
\hline Telephone Number series W & .004 & 1.02 & & & & \\
\hline Face to Face Num series & & & .019 & 3.00 & -.007 & 0.81 \\
\hline Episodic memory & .017 & 2.49 & .017 & 2.53 & .012 & 1.59 \\
\hline TICS Mental status & .023 & 2.00 & .018 & 1.48 & .008 & 0.59 \\
\hline Numeracy & .315 & 2.20 & .199 & 1.34 & .207 & 1.33 \\
\hline Retrieval fluency & -.037 & 1.46 & -.036 & 1.44 & -.036 & 1.36 \\
\hline Calculation & & & & & .015 & 1.62 \\
\hline Matrix reasoning & & & & & .082 & 3.43 \\
\hline Mean financial literacy score & & & & & .280 & 2.83 \\
\hline Cons & 17.980 & 1.40 & 10.860 & 0.82 & 14.399 & 0.98 \\
\hline
\end{tabular}

Table 5.B

Predicting Financial Literacy

\begin{tabular}{lccc}
\hline & Coef & $\mathrm{t}$ & \\
\hline Age & .1067 & 2.32 & $\cdot$ \\
Age squared & -0007 & 2.05 & $\cdot$ \\
Couple & .1493 & 1.64 & \\
Education $^{\mathrm{a}}$ & .0640 & 2.98 &. \\
Income $^{\mathrm{a}}$ & .0033 & 3.78 & \\
Income squared $^{\mathrm{a}}$ & $-0330 \mathrm{e}-07$ & 3.42 &. \\
Cognition Variables & & & $\cdot$ \\
Face to Face Num series $_{\text {Episodic memory }}$ & .0082 & 2.72 \\
TICS Mental status & .0048 & 1.75 \\
Numeracy & .0024 & 0.51 \\
Retrieval fluency & .1318 & 2.31 \\
Calculation & .0058 & 0.59 \\
Matrix reasoning & .0065 & 1.91 \\
Cons & .0067 & 0.77 \\
\end{tabular}

a- income measured in thousands of dollars 


\section{Table 6}

Total Wealth by Numeracy of Spouse

(wealth in thousands of dollars)

Total Wealth

\begin{tabular}{ccccr}
\hline \multirow{2}{*}{$\begin{array}{c}\text { Numeracy Score of } \\
\text { Financial Respondent }\end{array}$} & 0 & 1 & 2 & 3 \\
\hline 0 & 202.3 & 339.8 & 548.5 & $1,762.1$ \\
1 & 431.5 & 505.1 & 682.9 & 564.9 \\
2 & 684.5 & 685.8 & 852.6 & $1,357.5$ \\
3 & 971.5 & 818.3 & 949.6 & $1,679.4$ \\
\hline
\end{tabular}

Total Financial Wealth

Numeracy Score of

Numeracy Score of Spouse of Non-Financial Respondent

\begin{tabular}{crrrr} 
Financial Respondent & 0 & 1 & 2 & 3 \\
\hline 0 & 94.7 & 184.1 & 283.0 & 1450.9 \\
1 & 272.6 & 331.8 & 461.0 & 317.6 \\
2 & 466.7 & 445.7 & 545.3 & 888.5 \\
3 & 620.0 & 536.8 & 648.6 & $1,066.0$ \\
\hline
\end{tabular}

Fraction of Financial Wealth in Stocks

\begin{tabular}{crrrc}
\hline & \multicolumn{4}{c}{ Numeracy Score of Spouse of Non-Financial Respondent } \\
Numeracy Score of & 0 & 1 & 2 & 3 \\
Financial Respondent & 3.0 & 6.3 & 9.4 & 16.8 \\
\hline 0 & 6.1 & 9.0 & 11.0 & 11.6 \\
1 & 9.8 & 11.7 & 13.5 & 15.9 \\
2 & 11.4 & 18.1 & 17.0 & 17.5 \\
3 & & &
\end{tabular}




\section{Table 7}

Means of Cognition Variables by Gender and Whether Financial Respondent (sample of married families)

\begin{tabular}{|l|c|c|c|c|}
\hline & Male & Female & $\begin{array}{c}\text { Financial } \\
\text { Respondent }\end{array}$ & $\begin{array}{c}\text { Non- } \\
\text { Financial } \\
\text { Respondent }\end{array}$ \\
\hline $\begin{array}{l}\text { Number Series } \\
\text { (W-scale) }\end{array}$ & 505.4 & 500.3 & 504.7 & 500.6 \\
\hline $\begin{array}{l}\text { TICS Mental Status } \\
(0-10)\end{array}$ & 8.958 & 8.924 & 9.125 & 8.735 \\
\hline $\begin{array}{l}\text { Word Recall } \\
(0-10)\end{array}$ & 4.704 & 5.377 & 5.086 & 5.016 \\
\hline $\begin{array}{l}\text { Retrieval Fluency } \\
(\text { W scale) }\end{array}$ & 495.7 & 498.4 & 497.4 & 496.8 \\
\hline $\begin{array}{l}\text { Numeracy } \\
(0-3)\end{array}$ & 1.464 & 1.169 & 1.450 & 1.165 \\
\hline
\end{tabular}

\begin{tabular}{|l|c|c|c|c|}
\hline & Male & Male & Female & Female \\
\hline & $\begin{array}{c}\text { Financial } \\
\text { Respondent }\end{array}$ & $\begin{array}{c}\text { Non- } \\
\text { Financial } \\
\text { Respondent }\end{array}$ & $\begin{array}{c}\text { Financial } \\
\text { Respondent }\end{array}$ & $\begin{array}{c}\text { Non- } \\
\text { Financial } \\
\text { Respondent }\end{array}$ \\
\hline $\begin{array}{l}\text { Number Series } \\
\text { (W-scale) }\end{array}$ & 508.2 & 500.8 & 500.1 & 500.5 \\
\hline $\begin{array}{l}\text { TICS Mental } \\
\text { Status } \\
(0-10)\end{array}$ & 9.203 & 8.505 & 8.974 & 8.893 \\
\hline $\begin{array}{l}\text { Word Recall } \\
(0-10)\end{array}$ & 4.883 & 4.378 & 5.399 & 5.362 \\
\hline $\begin{array}{l}\text { Retrieval } \\
\text { Fluency } \\
\text { (W scale) }\end{array}$ & 1.606 & 1.205 & 1.209 & 498.1 \\
\hline $\begin{array}{l}\text { Numeracy } \\
(0-3)\end{array}$ & 494.4 & 498.8 & 1.143 \\
\hline
\end{tabular}

Note. HRS $2006-62 \%$ of financial respondents are men. 
Table 8

Correlations of Cognition Scores of Husbands and Wives

\begin{tabular}{|c|c|c|c|c|c|c|c|c|c|c|}
\hline & $\begin{array}{c}\text { Husband } \\
\text { Number } \\
\text { Series }\end{array}$ & $\begin{array}{c}\text { Husband } \\
\text { Mental } \\
\text { Status }\end{array}$ & $\begin{array}{c}\text { Husband } \\
\text { Word } \\
\text { Recall }\end{array}$ & $\begin{array}{l}\text { Husband } \\
\text { Numeracy }\end{array}$ & $\begin{array}{c}\text { Husband } \\
\text { Retrieval } \\
\text { Fluency }\end{array}$ & $\begin{array}{c}\text { Wife } \\
\text { Number } \\
\text { Series }\end{array}$ & $\begin{array}{c}\text { Wife } \\
\text { Mental } \\
\text { Status }\end{array}$ & $\begin{array}{l}\text { Wife } \\
\text { Word } \\
\text { Recall }\end{array}$ & $\begin{array}{c}\text { Wife } \\
\text { Numeracy }\end{array}$ & $\begin{array}{c}\text { Wife } \\
\text { Retrieval } \\
\text { Fluency }\end{array}$ \\
\hline $\begin{array}{l}\text { Husband } \\
\text { Number } \\
\text { Series W }\end{array}$ & 1.000 & & & & & & & & & \\
\hline $\begin{array}{l}\text { Husband } \\
\text { TICS } \\
\text { Mental } \\
\text { Status }\end{array}$ & 0.058 & 1.000 & & & & & & & & \\
\hline $\begin{array}{l}\text { Husband } \\
\text { Word } \\
\text { Recall }\end{array}$ & 0.085 & 0.101 & 1.000 & & & & & & & \\
\hline $\begin{array}{l}\text { Husband } \\
\text { Numeracy }\end{array}$ & 0.078 & 0.111 & 0.570 & 1.000 & & & & & & \\
\hline $\begin{array}{l}\text { Husband } \\
\text { Retrieval } \\
\text { Fluency W }\end{array}$ & 0.143 & 0.063 & 0.070 & 0.064 & 1.000 & & & & & \\
\hline $\begin{array}{l}\text { Wife } \\
\text { Number } \\
\text { Series W }\end{array}$ & NA & NA & $\mathrm{NA}$ & NA & $\mathrm{NA}$ & 1.000 & & & & \\
\hline $\begin{array}{l}\text { Wife TICS } \\
\text { Mental } \\
\text { Status }\end{array}$ & -0.000 & 0.504 & -0.178 & -0.090 & 0.028 & 0.021 & 1.000 & & & \\
\hline $\begin{array}{l}\text { Wife Word } \\
\text { Recall }\end{array}$ & 0.010 & -0.137 & 0.177 & 0.167 & 0.014 & 0.059 & -0.078 & 1.000 & & \\
\hline $\begin{array}{l}\text { Wife } \\
\text { Numeracy }\end{array}$ & 0.010 & -0.079 & 0.153 & 0.229 & 0.038 & 0.057 & -0.049 & 0.430 & 1.000 & \\
\hline $\begin{array}{l}\text { Wife } \\
\text { Retrieval } \\
\text { Fluency W }\end{array}$ & NA & NA & $\mathrm{NA}$ & NA & NA & 0.121 & 0.045 & 0.031 & 0.004 & 1.000 \\
\hline
\end{tabular}


Table 9.A

Relationship of Household Wealth Holdings to Cognition of Both

Financial and Non-Financial Respondents

2006 sample of married couples

Robust Regression

(wealth in thousands of dollars)

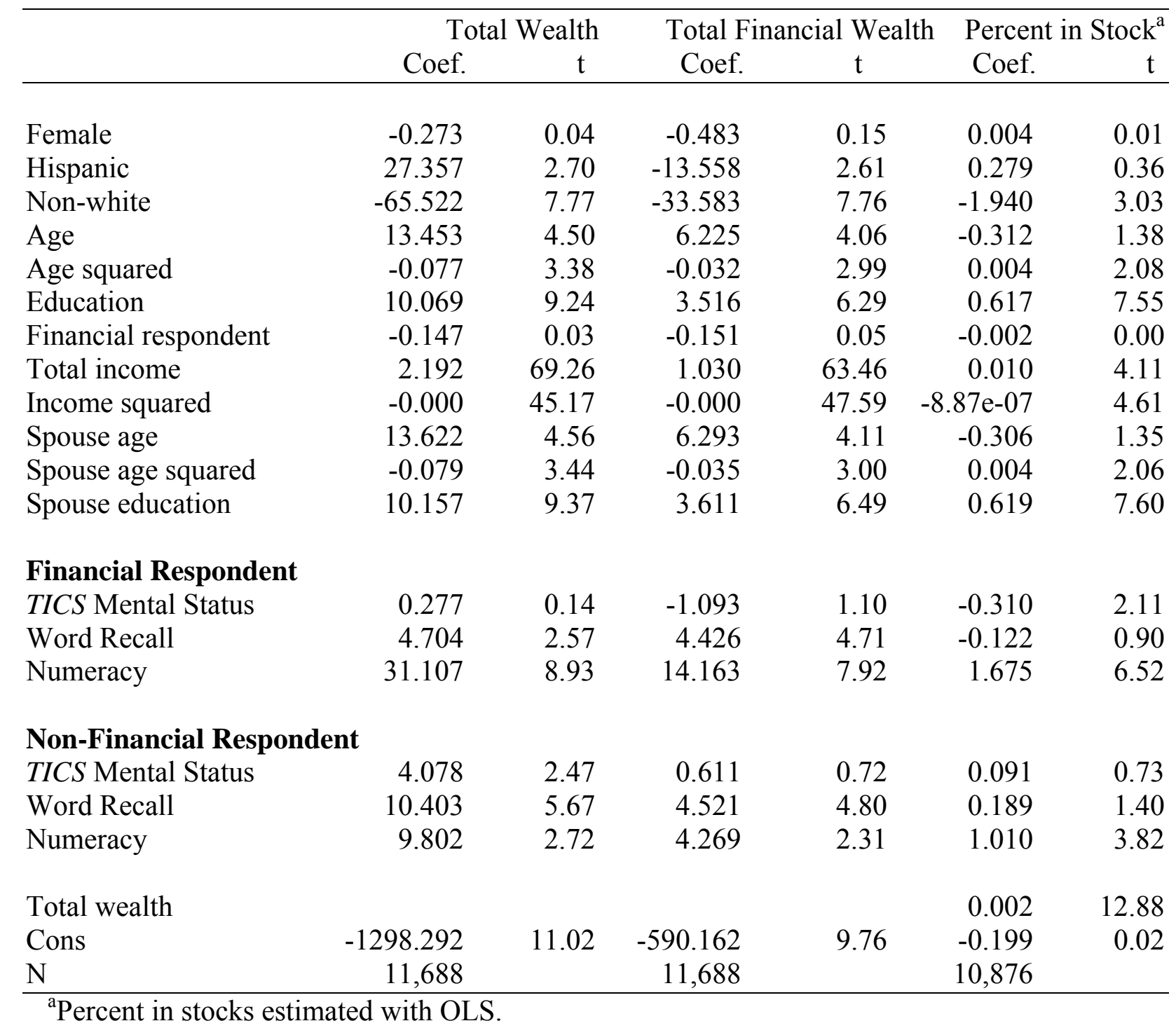


Table 9.B

Relationship of Change in Household Wealth Holdings (2006-2000) to Cognition

2006 Couple Sample-Robust Regression

(wealth in thousands of dollars)

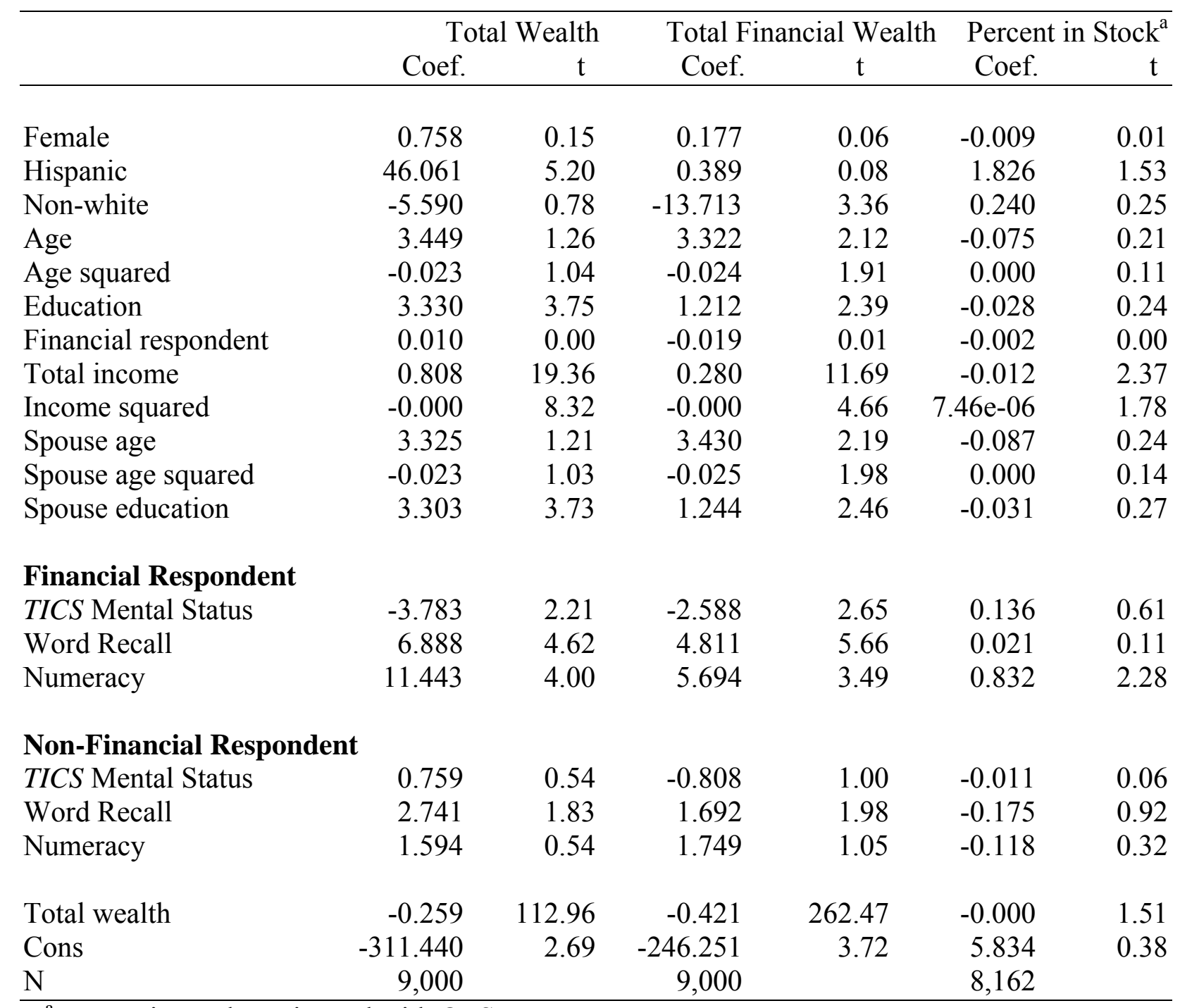

${ }^{\mathrm{a}}$ Percent in stocks estimated with OLS. 
Table 10

Relationship of Household Wealth Holdings to Cognition of Both

Financial and Non-Financial Respondents

2006 sample of married couples

Quantile Models

(wealth in thousands of dollars)

\begin{tabular}{lrrrrrr}
\hline & \multicolumn{2}{c}{$25^{\text {th }}$ Quantile } & \multicolumn{2}{c}{ Median } & \multicolumn{2}{r}{$75^{\text {th }}$ Quantile } \\
& Coef. & $\mathrm{t}$ & \multicolumn{1}{c}{ Coef. } & $\mathrm{t}$ & Coef. & $\mathrm{t}$ \\
\hline & & & & & & \\
Female & -0.397 & 0.09 & -0.450 & 0.08 & -1.129 & 0.09 \\
Hispanic & 12.922 & 1.72 & 50.321 & 5.68 & 87.513 & 4.40 \\
Non-white & -27.584 & 4.52 & -51.208 & 6.95 & -92.610 & 5.50 \\
Age & 8.732 & 4.26 & 10.886 & 4.18 & 22.667 & 3.48 \\
Age squared & -0.049 & 3.06 & -0.056 & 2.80 & -0.126 & 2.57 \\
Education & 5.017 & 6.69 & 9.593 & 10.07 & 14.400 & 6.14 \\
Fin respondent & 0.194 & 0.05 & 0.553 & 0.11 & -0.753 & 0.07 \\
Total income & 1.917 & 83.24 & 3.368 & 121.65 & 6.539 & 94.54 \\
Income squared & -0.000 & 56.82 & -0.000 & 94.75 & -0.000 & 85.24 \\
Spouse age & 8.968 & 4.36 & 11.353 & 4.35 & 21.472 & 3.32 \\
Spouse age squared & -0.051 & 3.17 & -0.058 & 2.90 & -0.119 & 2.43 \\
Spouse education & 4.932 & 6.60 & 9.855 & 10.40 & 14.355 & 6.16 \\
& & & & & & \\
Financial Respondent & & & & & & \\
TICS Mental Status & -0.168 & 0.12 & 0.098 & 0.06 & -6.286 & 1.53 \\
Word Recall & 4.417 & 3.36 & 3.843 & 2.40 & 6.532 & 1.70 \\
Numeracy & 16.841 & 6.81 & 37.857 & 12.42 & 71.464 & 9.74 \\
& & & & & & \\
Non-Financial Respondent & & & & & & \\
TICS Mental Status & 1.297 & 1.11 & 2.122 & 1.47 & 3.595 & 1.04 \\
Word Recall & 7.760 & 6.00 & 6.949 & 4.23 & 3.383 & 0.88 \\
Numeracy & 6.628 & 2.28 & 20.285 & 5.41 & 22.547 & 2.98 \\
Cons & -895.353 & 11.13 & -1193.727 & 5.99 & $-2,049.343$ & 7.88 \\
N & 11,688 & & 11,688 & & 11,688 & \\
\hline
\end{tabular}

\begin{tabular}{|c|c|c|}
\hline & \multicolumn{2}{|c|}{$90^{\text {th }}$ Quantile } \\
\hline & Coef. & $\mathrm{t}$ \\
\hline Female & 0.599 & 0.02 \\
\hline Hispanic & 215.708 & 5.84 \\
\hline Non-white & -108.479 & 3.33 \\
\hline Age & 23.861 & 1.73 \\
\hline Age squared & -0.121 & 1.18 \\
\hline Education & 22.218 & 4.57 \\
\hline Financial respondent & 0.422 & 0.02 \\
\hline
\end{tabular}




$\begin{array}{lrr}\text { Total income } & 11.315 & 84.41 \\ \text { Income squared } & -0.001 & 79.92 \\ \text { Spouse age } & 23.299 & 1.72 \\ \text { Spouse age squared } & -0.118 & 1.17 \\ \text { Spouse education } & 23.326 & 4.89\end{array}$

\section{Financial Respondent}

$\begin{array}{lll}\text { TICS Mental Status } & -2.947 & 0.37\end{array}$

$\begin{array}{lll}\text { Word Recall } & 16.193 & 2.16\end{array}$

$\begin{array}{lll}\text { Numeracy } & 102.421 & 7.19\end{array}$

\section{Non-Financial Respondent}

TICS Mental Status

Word Recall

$\begin{array}{ll}-3.716 & 0.54\end{array}$

Numeracy

$9.898 \quad 1.29$

Cons

$71.034 \quad 4.55$

$\mathrm{N}$

$-2363.323 \quad 4.26$


Table 11

Relationship of Total Financial Wealth to Cognition of Both

Financial and Non-Financial Respondents

2006 sample of married couples

Quantile Models

(wealth in thousands of dollars)

\begin{tabular}{lrrrrrr}
\hline & \multicolumn{2}{c}{$25^{\text {th }}$ Quantile } & \multicolumn{2}{c}{ Median } & \multicolumn{2}{c}{$75^{\text {th }}$ Quantile } \\
& Coef. & $\mathrm{t}$ & Coef. & $\mathrm{t}$ & Coef. & $\mathrm{t}$ \\
\hline & & & & & & \\
Female & -0.023 & 0.01 & 0.0308 & 0.01 & -0.611 & 0.08 \\
Hispanic & -2.296 & 0.84 & 5.685 & 0.99 & 5.950 & 0.50 \\
Non-white & -12.359 & 5.55 & -26.533 & 5.55 & -66.479 & 6.48 \\
Age & 4.1000 & 5.62 & 5.336 & 3.15 & 9.881 & 2.53 \\
Age squared & -0.025 & 4.40 & -0.028 & 2.11 & -0.052 & 1.77 \\
Education & 1.244 & 4.49 & 3.343 & 5.41 & 5.671 & 4.03 \\
Financial respondent & -0.011 & 0.01 & -0.071 & 0.02 & -0.302 & 0.04 \\
Total income & 0.922 & 121.81 & 2.226 & 123.97 & 5.226 & 121.42 \\
Income squared & -0.000 & 98.89 & -0.000 & 108.58 & -0.000 & 116.71 \\
Spouse age & 4.107 & 5.63 & 5.203 & 3.07 & 10.180 & 2.59 \\
Spouse age squared & -0.025 & 4.41 & -0.027 & 2.05 & -0.0551 & 1.85 \\
Spouse education & 1.235 & 4.49 & 3.334 & 5.42 & 5.940 & 4.25 \\
& & & & & & \\
Financial Respondent & & & & & & \\
TICS Mental Status & -0.780 & 1.60 & -1.613 & 1.48 & -2.571 & 1.02 \\
Word Recall & 1.214 & 2.58 & 2.984 & 2.88 & 1.015 & 0.44 \\
Numeracy & 5.439 & 6.14 & 17.171 & 8.69 & 42.099 & 9.46 \\
Non-Financial Respondent & & & & & & \\
TICS Mental Status & -0.562 & 1.35 & 0.044 & 0.05 & 0.204 & 0.10 \\
Word Recall & 1.979 & 4.31 & 2.497 & 2.40 & 2.263 & 0.99 \\
Numeracy & 1.591 & 1.76 & 9.961 & 4.88 & 9.703 & 2.11 \\
Cons & & & & & & \\
N & -364.185 & 12.72 & -556.740 & 8.33 & -4380.231 & 5.12 \\
\hline
\end{tabular}

\begin{tabular}{lrr}
\hline & \multicolumn{2}{c}{$90^{\text {th }}$ Quantile } \\
& Coef. & $\mathrm{t}$ \\
\hline Female & & \\
Hispanic & -3.880 & 0.22 \\
Non-white & 100.347 & 3.78 \\
Age & -102.394 & 4.34 \\
Age squared & 10.633 & 1.01 \\
Education & -0.041 & 0.53 \\
& 15.086 & 4.30
\end{tabular}


Financial respondent

$-2.998$

0.18

Total income

8.600

89.74

Income squared

$-0.001 \quad 87.93$

Spouse age

11.626

1.12

Spouse age squared

$\begin{array}{ll}-0.049 & 0.63\end{array}$

Spouse education

$16.241 \quad 4.68$

\section{Financial Respondent}

\section{TICS Mental Status}

$-5.602$

11.405

0.94

Word Recall

68.350

2.14

Numeracy

6.58

\section{Non-Financial Respondent}

TICS Mental Status

$\begin{array}{ll}-3.206 & 0.63\end{array}$

Word Recall

$-0.600 \quad 0.10$

Numeracy

$28.724 \quad 2.56$

Cons

-1240.893
11,688

2.98

$\mathrm{N}$

11,688 
Table 12.A

Percent of Men Who Are Financial Respondents, by Age of Both Spouses (Sample of Married Couples)

\begin{tabular}{cccccc}
\hline & \multicolumn{5}{c}{ Age of Wife } \\
\cline { 2 - 6 } & $\leq 59$ & $60-69$ & $70-79$ & $\geq 80$ & All \\
\hline \multicolumn{2}{c}{ Age of Husband } & & & & \\
$\leq 59$ & 59.1 & 40.9 & NA & NA & 57.4 \\
$60-69$ & 69.6 & 62.0 & 56.1 & NA & 64.1 \\
$70-79$ & 82.8 & 61.8 & 60.1 & 57.7 & 61.8 \\
$\geq 80$ & NA & 56.9 & 57.9 & 67.1 & 62.9 \\
All & 63.5 & 60.7 & 59.1 & 65.3 & 61.6 \\
\hline
\end{tabular}

NA. Sample size less than 20.

Table 12.B

Percent of Men Who Are Financial Respondents, by Education of Both Spouses

Education of Wife

\begin{tabular}{llll}
\hline$<\mathrm{HSG}$ & HSG & College or More & All
\end{tabular}

Education of Husband

$<$ High School

High School

College Grad

55.4

68.5

44.7

58.3

38.5

49.9

88.2

75.6

55.6

59.6

61.1

59.5

75.4

75.9

All

61.1

67.6

61.6 


\section{Table 13}

OLS Predicting If Male Is Financial Respondent (Sample of Married Couples)

\begin{tabular}{|c|c|c|c|}
\hline & Coef. & $\mathrm{t}$ & $\begin{array}{c}\text { "F test" for Difference } \\
\text { Between } \\
\text { Male and Female } \\
\text { Coefficient }\end{array}$ \\
\hline Total income & 0.0001 & 1.48 & \\
\hline Income squared & $-5.79 e-09$ & 0.98 & \\
\hline \multicolumn{4}{|l|}{ Husband } \\
\hline Age $<59$ & -0.2077 & 5.81 & \\
\hline Age $60-69$ & -0.0763 & 2.57 & \\
\hline Age $70-79$ & -0.0451 & 1.79 & \\
\hline Education & 0.0212 & 9.00 & \\
\hline TICS mental status & 0.0157 & 3.79 & \\
\hline Word recall & 0.0249 & 5.46 & \\
\hline Numeracy & 0.0800 & 9.72 & \\
\hline \multicolumn{4}{|l|}{ Wife } \\
\hline$\overline{\text { Spouse age }<59}$ & 0.1580 & 4.12 & 1.96 \\
\hline Spouse age $60-69$ & 0.0240 & 0.72 & 3.30 \\
\hline Spouse age $70-79$ & -0.0341 & 1.13 & 8.01 \\
\hline Spouse education & -0.0115 & 4.35 & 13.37 \\
\hline Spouse TICS mental status & -0.0006 & 0.15 & 7.07 \\
\hline Spouse word recall & -0.0124 & 3.00 & 4.44 \\
\hline Spouse numeracy & -0.0568 & 6.95 & 4.42 \\
\hline Cons & 0.3305 & 5.81 & \\
\hline
\end{tabular}




\section{Life Cycle Pattern of Fluid and Crystallized Intelligence}

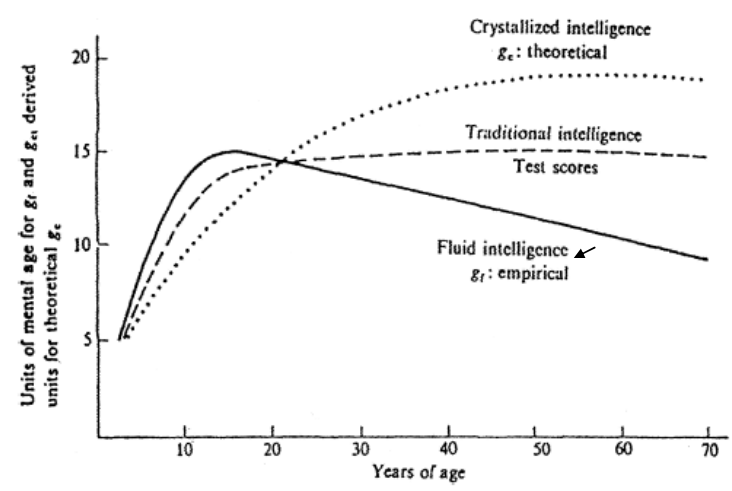

Figure 1. A theoretical description of life span curves of intellectual abilities. From Intelligence: Its structure, growth and action (p. 206) by R. B. Cattell, 1987, Amsterdam: North-Holland. Copyright 1987 by Elsevier Science Publishers. Reprinted with permission. 
Figure 2. Wealth by Numeracy Score of Husband and Wife

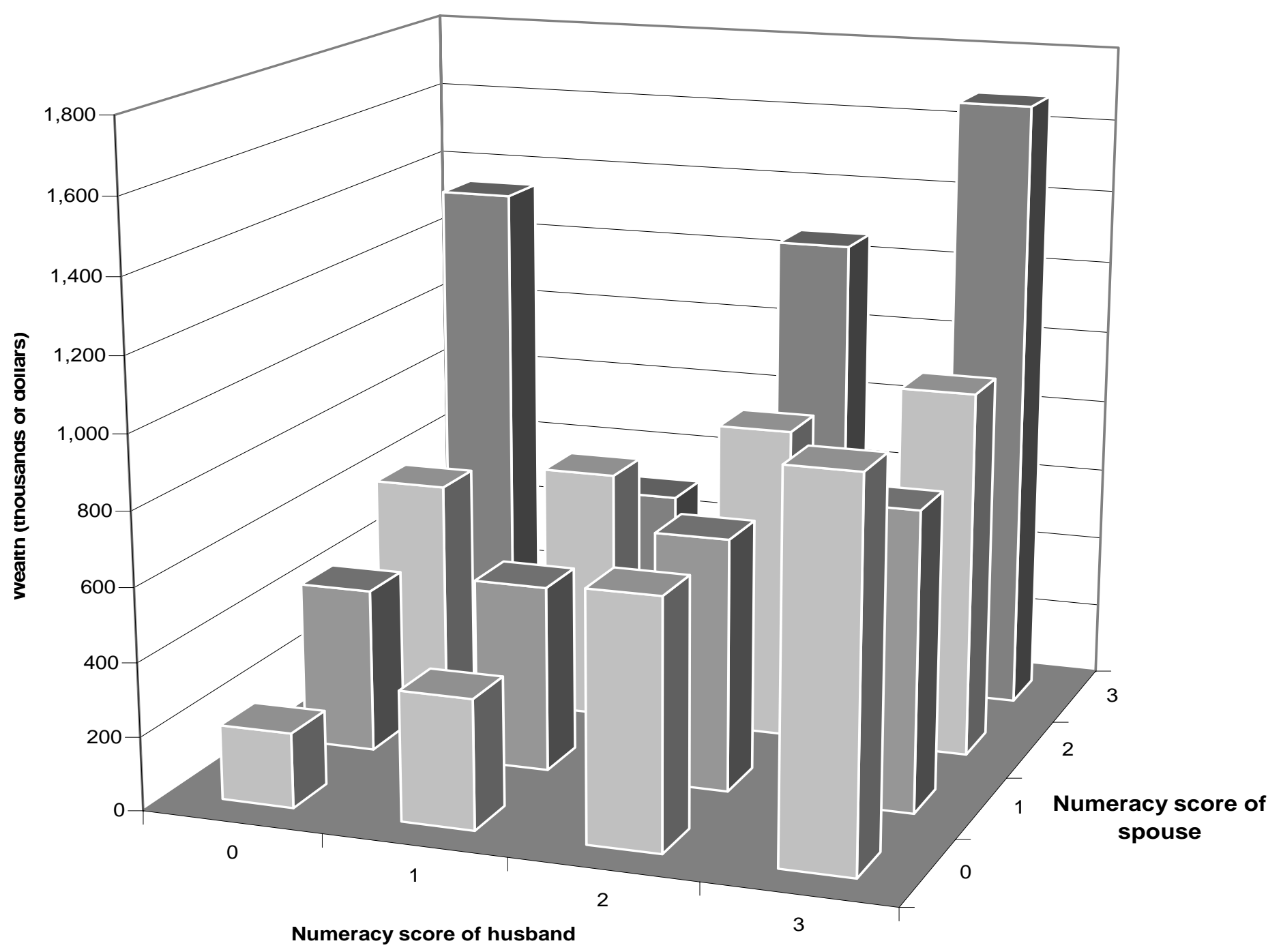

Total Wealth 